\title{
Toxicity and pharmacokinetic biomarkers for personalized non-small cell lung cancer treatment
}

Anna Svedberg 


\title{
Toxicity and pharmacokinetic biomarkers for personalized non-small cell lung cancer treatment
}

\author{
Anna Svedberg
}

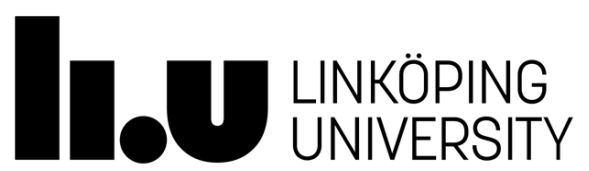

\author{
Division of Drug Research \\ Department of Biomedical and Clinical Sciences \\ Linköping University, Sweden
}

Linköping 2020 
(c) Anna Svedberg, 2020

ISBN 978-91-7929-982-8

ISSN 0345-0082

Printed in Sweden by LiU-Tryck, Linköping, Sweden, 2020

During the course of the research underlying this thesis, Anna Svedberg was enrolled in Forum Scientium, a multidisciplinary doctoral program at Linköping University, Sweden.

Published articles have been reprinted with the permission of the copyright holder.

Cover includes a modified picture from https://pixabay.com/ 
"If we knew what it was we were doing, it would not be called research, would it?"

- Albert Einstein 



\section{CONTENTS}

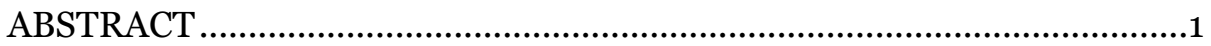

SVENSK SAMMANFATTNING …………………................................. 3

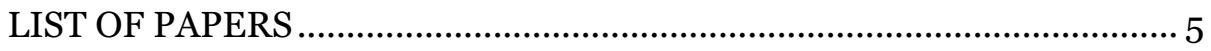

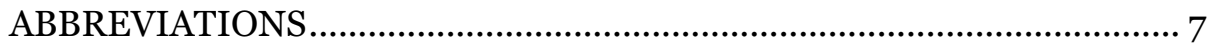

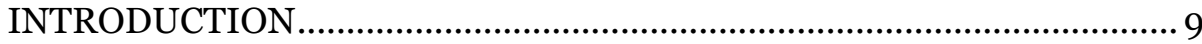

Non-small cell lung cancer....................................................................... 9

Treatment options ……........................................................................ 10

Chemotherapy with gemcitabine and carboplatin .................................. 11

EGFR targeted therapy with erlotinib .................................................... 12

Inter-individual variation in response and toxicity ..............................13

Inter-individual variability in erlotinib treatment ................................ 14

Pharmacokinetic variability in erlotinib treatment.................................. 14

Pharmacogenetic variability in erlotinib treatment ................................. 15

Pharmacogenetic variability in gemcitabine/carboplatin treatment . 16

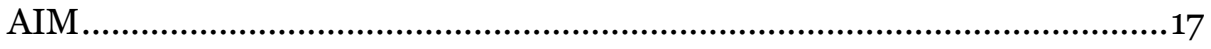

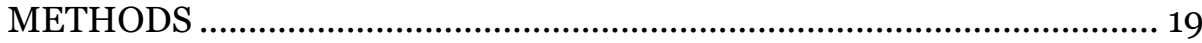

Patient cohorts and study designs ....................................................... 19

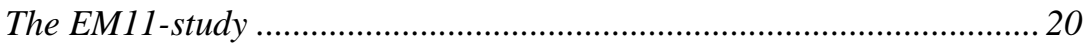

The gemcitabine/carboplatin study ..................................................... 21

Liquid Chromatography ......................................................................... 22

Assessment of CYP3A activity ................................................................ 23

Quinine as a probe for CYP3A activity ................................................... 23

The HPLC method with fluorescence detection ....................................... 23

Quantification of erlotinib and its metabolites .................................... 24

Metabolite production using human liver microsomes ............................ 24

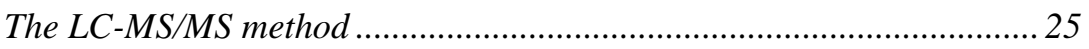

In vitro studies of ABCG2 mediated erlotinib transport...................... 27

Assessment of genetic variability by genotyping and sequencing ......28 


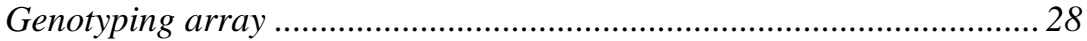

Fragment analysis and capillary electrophoresis.............................. 29

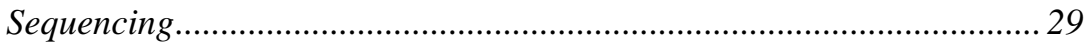

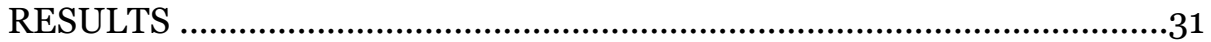

Chromatography method development..........................................31

Quantification of Erlotinib and its metabolites (paper I) ..................... 31

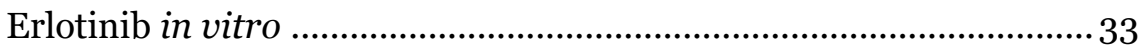

ABCG2 transport (paper IV) ....................................................... 33

Erlotinib pharmacokinetics in vivo ................................................. 34

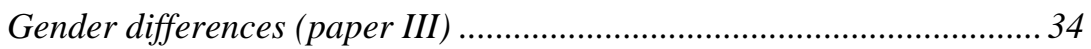

Erlotinib plasma trough concentrations (paper III) ............................ 35

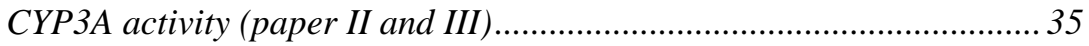

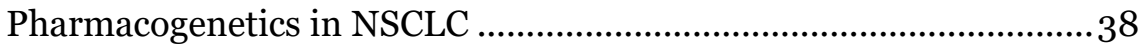

Erlotinib induced skin rash and diarrhea (paper III) ......................... 38

Gemcitabine/carboplatin induced leukopenia and neutropenia (paper V)

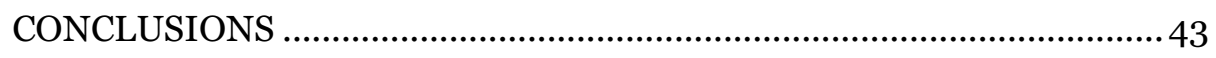

FUTURE ASPECTS .............................................................. 45

ACKNOWLEDGMENTS ................................................................. 47

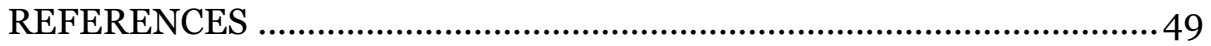




\section{ABSTRACT}

Lung cancer is the leading cause of cancer-related deaths worldwide. Unfortunately, lung cancer is usually discovered at a late stage when the curative treatment options are limited. The treatment can include surgery, radiation, chemotherapy, targeted therapy and now also immunotherapy.

The challenge in cancer treatment is to eradicate cancer by the use of harsh treatments, while still, keeping the patient alive. For this purpose, treatments with severe toxicities are usually accepted but regularly lead to dose reductions or postponed treatment. Large variations in response are generally observed between patients treated with the same drug at the same dose. The dose may be adequate in one patient while ineffective or cause severe adverse drug reactions in other patients. The occurrence of druginduced toxicities can, however, also be a positive indicator of treatment response. In personalized treatment it is of importance to select the most suitable treatment option and give it at the most favorable dose, to enable the patients to stay on treatment during the time the treatment is able to affect cancer since the tumor commonly develops resistance towards the treatment eventually.

In this thesis, inter-individual variability in pharmacokinetics and toxicity for the targeted therapy erlotinib, associated with the adverse events skin rash and diarrhea was studied. Inter-individual variability in toxicity was also studied for the chemotherapy treatment gemcitabine/carboplatin linked to the hematological toxicities neutropenia and leukopenia.

Erlotinib was studied in papers I-IV. Erlotinib and its metabolite concentrations were determined using a validated LC-MS/MS method. Diarrhea was associated with erlotinib and the metabolite M13, while skin rash was associated with the activity of the erlotinib metabolizing enzyme CYP3A and the ABCG2 single nucleotide polymorphism rs10856870. CYP3A was also shown to be induced during treatment. Additionally, in vitro studies showed that genetic variability in ABCG2 contributes to differences in intracellular concentrations. Genes and gene variants were found to be associated with gemcitabine/carboplatin-induced toxicity in paper V. The variants were partially validated, and two models were developed to estimate the risk of leukopenia or neutropenia based on a set of genetic variants. 


\section{SVENSK SAMMANFATTNING}

Lungcancer är den cancerform som leder till flest antal dödsfall runt om i världen. Tyvärr upptäcks lungcancer oftast i ett sent skede när möjligheten att bota cancern är begränsad. Lungcancer kan behandlas med flera behandlingsmetoder, antingen enskilt eller i kombination, som till exempel kirurgi, strålning, cellgifter, målriktad behandling eller immunoterapi.

Den stora svårigheten vid cancerbehandling är att eliminera cancern samtidigt som patienten klarar av behandlingen. Cancerbehandling innefattar ofta starka läkemedel som vanligtvis kan ge upphov till svåra biverkningar som resulterar i dosreduktion, uppehåll i behandling eller till och med avslutad behandling. Det finns idag flera behandlingsalternativ att välja mellan. Det är därför av stor vikt att välja en behandlingsmetod som cancertumören svarar på, samtidigt som behandlingen ges i rätt dos för nå önskad effekt. Det finns idag stor variation mellan patienter i hur de svarar på cancerbehandling, vissa patienter făr bra effekt av behandlingen medan andra patienter inte får någon effekt alls eller får svåra biverkningar. Tumören har en förmåga att efter en tid utveckla resistens. Det är därför viktigt att patienten behandlas effektivt mot cancern under en så lång period som möjligt när det finns en effekt mot tumören.

I den här avhandlingen har två olika behandlingar vid icke-småcellig lungcancer studerats för att bättre förstå vad som orsakar variation mellan patienter. Den ena behandlingen är en målriktad behandling med erlotinib (Tarceva) som vanligtvis ger biverkningar i form av hudutslag eller diarré. Den andra studerade behandlingen är en kombination av cellgifter, gemcitabin tillsammans med karboplatin, som vanligtvis ger biverkningarna leukopeni och neutropeni som leder till försämrat immunförsvar.

I delarbete I-IV studerades erlotinib, antingen via ett modellsystem i form av en cellinje eller från behandlade lungcancerpatienter. Variation av läkemedelskoncentrationer samt genetisk variation i arvsmassan studerades. Läkemedelskoncentrationer i erlotinibpatienters blod analyserades med en utvecklad och validerad kromatografimetod. Diarré visade sig vara kopplat till koncentrationen av erlotinib och metaboliten M13. Hudbiverkningar var associerade med CYP3A aktivitet, som är enzymet som bryter ner erlotinib i kroppen. CYP3A visade sig också att öka sin aktivitet i samband med att man påbörjar erlotinibbehandling. Hudbiverkningar kopplades också till en kvot av metaboliter (OSI-420/didesmethyl erlotinib) och en 
naturlig genetisk variation i $A B C G 2$-genen som är involverad i transport av erlotinib ut ur kroppen.

I delarbete $\mathrm{V}$ studerades genetisk variation i gemcitabin/carboplatin behandlade lungcancerpatienter. Då identifierades naturlig genetisk variation i arvsmassan kunna förklara en del av variationen i uppkomsten av biverkningar. Flera genetiska varianter användes för att bygga modeller som kan användas för att förutspå om patienter löper hög risk att drabbas av svåra cellgiftsbiverkningar. 


\section{LIST OF PAPERS}

I. A validated liquid chromatography-tandem mass spectrometry method for quantification of erlotinib, OSI-42O and didesmethyl erlotinib and semi-quantification of erlotinib metabolites in human plasma

Anna Svedberg, Henrik Gréen, Anders Vikström, Joakim Lundeberg and Svante Vikingsson.

Journal of Pharmaceutical and Biomedical Analysis (2015)

II. Erlotinib treatment induces cytochrome P450 3A activity in non-small cell lung cancer patients

Svedberg A, Vikingsson S, Vikström A, Hornstra N, Kentson M, Branden E, Koyi H, Bergman B, Gréen H.

British Journal of Clinical Pharmacology (2019)

III. Identification of biomarkers in erlotinib treated non-small cell lung cancer patients

Anna Svedberg, Svante Vikingsson, Anders Vikström, Niels Hornstra, Magnus Kentson, Eva Brandén, Hirsh Koyi, Bengt Bergman, and Henrik Gréen.

Manuscript

IV. The influence of ABCG2 polymorphism on erlotinib efflux in the K562 cell line

Anna Svedberg, Lianne Jacobs, Svante Vikingsson and Henrik Gréen.

Submitted to pharmacology research and perspectives

V. A whole-exome sequencing study of gemcitabine/carboplatin induced leukopenia and neutropenia in non-small cell lung cancer patients

Anna Svedberg, Benjamín Sigurgeirsson, Niclas Björn, Sailendra Pradhananga, Eva Brandén, Hirsh Koyi, Rolf Lewensohn, Luigi De Petris, María Apellániz-Ruiz, Cristina Rodríguez-Antona, Joakim Lundeberg and Henrik Gréen.

Manuscript 
Other co-authored papers, not included in the thesis:

Genes and variants in hematopoiesis-related pathways are associated with gemcitabine/carboplatin-induced thrombocytopenia.

Björn N, Sigurgeirsson B, Svedberg A, Pradhananga S, Brandén E, Koyi H, Lewensohn R, de Petris L, Apellániz-Ruiz M, Rodríguez-Antona C, Lundeberg J, Gréen H.

Pharmacogenomics J. 2019 Oct 15.

In Vivo Cytochrome P450 3A Isoenzyme Activity and Pharmacokinetics of Imatinib in Relation to Therapeutic Outcome in Patients With Chronic Myeloid Leukemia.

Skoglund K, Richter J, Olsson-Strömberg U, Bergquist J, Aluthgedara W,

Ubhayasekera SJ, Vikingsson S, Svedberg A, Söderlund S, Sandstedt A, Johnsson A, Aagesen J, Alsenhed J, Hägg S, Peterson C, Lotfi K, Gréen H.

Ther Drug Monit. 2016 Apr;38(2):230-8.

Novel rapid liquid chromatography tandem mass spectrometry method for vemurafenib and metabolites in human plasma, including metabolite concentrations at steady state.

Vikingsson S, Strömqvist M, Svedberg A, Hansson J, Höiom V, Gréen H.

Biomed Chromatogr. 2016 Aug;30(8):1234-9. 


\section{ABBREVIATIONS}

$\begin{array}{ll}\text { ABC } & \text { ATP-binding cassette } \\ \text { ADR } & \text { Adverse drug reaction } \\ \text { AE } & \text { Adverse events } \\ \text { AUC } & \text { Area under the curve } \\ \text { CDA } & \text { Cytidine deaminase } \\ \text { CTCAE } & \text { Common toxicity criteria for adverse events } \\ \text { CYP } & \text { Cytochrome P450 } \\ \text { EGFR } & \text { Epidermal growth factor receptor } \\ \text { EYFP } & \text { Enhanced yellow fluorescent protein } \\ \text { GWAS } & \text { Genome-wide association studies } \\ \text { HLM } & \text { Human liver microsome } \\ \text { HPLC } & \text { High-performance liquid chromatography } \\ \text { LC } & \text { Liquid chromatography } \\ \text { LLOQ } & \text { Lower limit of quantification } \\ \text { NSCLC } & \text { Non-small cell lung cancer } \\ \text { MAF } & \text { Minor allele frequency } \\ \text { MS/MS } & \text { Tandem mass spectrometry } \\ \text { OS } & \text { Overall survival }\end{array}$


PBS Phosphate-buffered saline

PFS Progression-free survival

TKI Tyrosine kinase inhibitor

TDM Therapeutic drug monitoring

SNP Single nucleotide polymorphism 


\section{INTRODUCTION}

\section{Non-small cell lung cancer}

Lung cancer is the leading cause of cancer-related deaths worldwide, but the mortality rate is decreasing [1]. Yearly, around 4000 Swedes are diagnosed with lung cancer [2], and the incidence of lung cancer is still slightly higher in males but the differences have almost disappeared. Lung cancer is divided into non-small cell lung cancer (NSCLC, 85\%) which confers a better prognosis compared to small cell lung cancer $[1,2]$. Non-small cell lung cancer is further subgrouped into adenocarcinoma, squamous cell carcinoma and large cell carcinoma.

Several risk factors have been associated with lung cancer [3]. One factor is the individual genetic composition that can increase the lung cancer risk based on natural genetic variation or based on a familial inherited predisposition to lung cancer [4-6]. The main risk factors for developing lung cancer is nevertheless smoking and the duration of smoking [7, 8]. Additionally, exposure to secondhand cigarette smoke increases the risk of developing lung cancer $[9,10]$. Other risk factors include, but are not limited to, ionizing radiation, radon, asbestos, silica, polycyclic aromatic hydrocarbons and air pollutions [11-14].

The long term survival of NSCLC strongly depends on the tumor stage at diagnosis. The 5-year relative survival rate for adenocarcinoma is $68.7 \%$, 
42.1\%, 6.5\% in localized, regional and distant stages, respectively [15]. The rates are slightly lower for squamous cell carcinoma and large cell carcinoma.

\section{Treatment options}

Depending on the tumor stage and the health of the patient, treatment options alone or in combination can include surgery, radiation, chemotherapy, targeted therapy, or immunotherapy. At the time of lung cancer diagnosis, approximately $70 \%$ of the patients have advanced NSCLC (stage III/IV) [16] and the possibility to cure the cancer is limited. The lower stage NSCLCs are usually treated with surgery, chemotherapy, and radiation, either alone or in combination. Treatment options in inoperable advanced NSCLC have increased in the last decades to not only include chemotherapy, but to also include targeted therapy and immunotherapy, Figure 1.

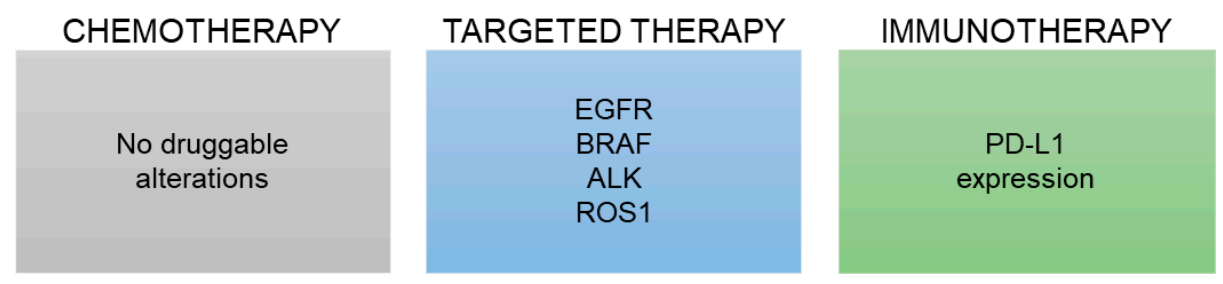

Figure 1: The different treatment options to select from in advanced NSCLC depend on the occurrence of mutations (EGFR and BRAF), translocations (ALK and ROS1) and expression of immune checkpoint proteins (PD-L1) in the tumors.

In common for all the above mentioned anti-cancer drugs are treatmentinduced toxicities due to narrow therapeutic windows. The adverse drug reactions vary depending on treatment options and are usually related to the mechanism of action of the drug. For instance, standard chemotherapy acts on rapidly dividing cancer cells, but also on other rapidly diving cells such as blood cells [17]. Targeted therapies are suggested to inhibit the wild-type target and immunotherapies are associated with immune-related adverse drug reactions $[18,19]$. Off-target effects causing adverse drug reactions are, however, also favored because these can be a sign that the treatment is effective [20].

The evaluation of toxicity is usually made according to the common terminology criteria of adverse events (CTCAE) [21]. CTCAE grades adverse events with increasing toxicity from grade 1 beeing mild to grade 5 , if possible, being death caused by an adverse drug reaction, Table 1 . 
Table 1: Grading of adverse drug reactions according to CTCAE.

\begin{tabular}{ccc} 
& Grade & Intervention \\
\hline 1 & Mild & Clinical or diagnostic observations only \\
2 & Moderate & Local or noninvasive intervention indicated \\
3 & Severe & Hospitalization indicated \\
4 & Life-threatening & Urgent interventions indicated \\
5 & Death & Death related to adverse events \\
\hline
\end{tabular}

\section{Chemotherapy with gemcitabine and carboplatin}

There are several different chemotherapy drugs available. Typically, a platinum drug is combined with another agent [22], such as the platinumbased chemotherapy doublet carboplatin in combination with gemcitabine. Gemcitabine and carboplatin are usually given intravenously in cycles of 3 weeks [23]. Gemcitabine is given on days 1 and 8 at a dose of $1250 \mathrm{mg} / \mathrm{m}^{3}$ and the carboplatin is given on day 1 at a dose required to reach area under the curve (AUC) 5 according to the Calvert formula.

Carboplatin is an alkylating agent. Positively charged carboplatin can bind to the negatively charged DNA in the nucleus to the guanine nucleotide forming platinum-DNA complexes. The monoadducts and intra- and interstrand crosslinks created by carboplatin interfere with transcription and/or DNA replication that eventually leads to cell death [24].

Gemcitabine is nucleoside analog to deoxycytidine and is classified as an antimetabolite [25, 26]. Gemcitabine is a probe drug and requires several phosphorylation steps to become a biologically active substance. Gemcitabine diphosphate indirectly contributes to inhibition of DNA synthesis by inhibition of the ribonucleotide reductase enzyme that is responsible for producing the dinucleotides required for DNA synthesis and repair. This leads to a decrease in deoxynucleotides which favor gemcitabine triphosphate in its competition with dCTP for incorporation into DNA. Gemcitabine triphosphate directly inhibits DNA synthesis by masked chain termination. Instead of dCTP, gemcitabine triphosphate incorporates into DNA, followed by one additional incorporated nucleotide. This disables further DNA synthesis and prevents the use of end repair mechanisms.

The dose-limiting toxicity of gemcitabine and carboplatin is myelosuppression, also known as hematological toxicity $[27,28]$. This leads to a reduction in the number of blood cells that are essential for immunity (leukocytes and neutrophils), coagulation (thrombocytes), and oxygen transport (red blood cells) and these lead to leukopenia, neutropenia, thrombocytopenia, and anemia, respectively. Signs of myelosuppression prior to initiating a new treatment cycle lead to actions such as dose reduction, treatment delay or treatment discontinuation in severe cases. Severe 
adverse events of grade 3-4 according to the CTCAE in patients undergoing gemcitabine/carboplatin treatment have been reported in around $20-70 \%$ of the study populations [23, 29-31].

The myelosuppressive toxicities can be managed by blood transfusion to improve the peripheral blood status or by addition of growth factors, such as granulocyte colony-stimulating factor that promotes myeloid cell generation, and in severe cases by bone marrow transplantation [32, 33].

\section{EGFR targeted therapy with erlotinib}

Several therapies have been developed to target specific oncogenic driver mutations or translocations in tumors, one of which is to target the epidermal growth factor receptor (EGFR).

Normal EGFR is essential for the development of several epidermal structures in the lung, skin, pancreas, gastrointestinal tract and central nervous system, and developmental defects are seen in EGFR knockout mice and dysregulated and overactive EGFR signaling is commonly seen in several cancer types [34-36]. EGFR signaling is initiated when EGF or other ligands bind to the extra-cellular EGFR. Ligand binding leads to the activation of the intracellular tyrosine kinase domain and ATP phosphorylates the tyrosines on the C-terminal end of the opposite EGFR monomer [37]. The phosphorylated tyrosines initiate further downstream signaling by binding to proteins associated with cellular responses such as cell proliferation, survival, motility, and differentiation. In cancer, EGFR mutations in the tyrosine kinase domain are suggested to destabilize the inactive state of the tyrosine kinase causing it to be in a constantly active state that leads to uncontrolled tumor growth [38, 39].

Dysregulated EGFR signaling in NSCLC can be treated with EGFR tyrosine kinase inhibitors (TKIs), for instance, erlotinib [40]. Unlike chemotherapy that is administered intravenously, erlotinib is taken as a tablet daily at a recommended dose of $150 \mathrm{mg}$. Erlotinib is approved as a first-line treatment in advanced NSCLC in patients with specific EGFR activating tumor mutations in the tyrosine kinase domain. The most common mutations - L858R and exon 19 deletions - requires a lower erlotinib concentration compared to wild type EGFR in order to inhibit the EGFR signaling. These mutations are present in around $10 \%$ of the Caucasian population and in around 35\% of the Asian population [41]. Erlotinib acts by preventing the phosphorylation of the tyrosine kinase domain by reversibly binding to the tyrosine kinase domain and blocking the binding site of ATP [42].

Skin rash and diarrhea are the typical adverse reactions to drugs targeting the EGFR signaling and lead to dose reductions and treatment discontinuations. Skin rash of any grade develops in around $75 \%$ of patients, while, diarrhea of any grade affects around $50 \%$ of patients [43-45]. EGFR 
is essential for proliferation, survival, and differentiation in the skin and gastrointestinal tract $[46,47]$. The skin rash appears after around 1 week [48] and is suggested to be due to the off-target effect of erlotinib acting in a dose-dependent manner on wildtype EGFR in the skin, creating an inflammatory response [49]. Diarrhea appears within the first 4 weeks of treatment and is suggested to be due to inhibitions of wildtype EGFR in the gastrointestinal tract causing dysregulated ion transport, inflammation, and mucosal injury [50-52].

Skin rash can be alleviated by the use of sunscreen, emollients and soap substitutes, antibiotics such as tetracyclines that also harbor anti-inflammatory properties, antihistamines or topical corticosteroids [53]. Diarrhea can be managed by changes in diet or antidiarrheal medication upon onset [50]. It is important to start the treatment for the erlotinib induced toxicities as soon as they appear in order to avoid unnecessary patient suffering.

\section{Inter-individual variation in response and toxicity}

The response to a drug of the same dose may vary between patients [54]. The dose may be adequate in one patient, but ineffective or cause adverse drug reactions in other patients.

The reason behind interindividual variation in response is usually an inadequate drug concentration that is not within the therapeutic window, which is the drug concentration interval required to obtain the desired therapeutic effect [55]. Drug concentrations below the therapeutic interval might lead to inadequate effects, while concentrations above can cause adverse drug reactions.

The drug concentration that is reached after drug exposure depends on both pharmacokinetic and pharmacodynamic processes [54]. Pharmacokinetic processes include the body's delivery of the drug to the site of action and the subsequent removal of the drug from the site of action over time. These events include absorption, distribution, metabolism, and elimination of the drug. Pharmacodynamic processes describe the action of a drug on its target and how well the target responds to the drug. Subsequently, both pharmacokinetic and pharmacodynamic processes are affected by genetic variations that can cause changes in drug exposure or alterations in the function of the drug target that then affect the drug response [56]. The study of how individual variation in DNA influences the drug response is called pharmacogenetics [57].

In personalized treatment, the aim is to be able to select the most suitable drug and give it at the most appropriate dose. Ideally, the response to a drug will be high while adverse drug reactions will be low. To enable a personalized treatment approach in NSCLC treatment it is important to 
study the possible underlying mechanisms that contribute to the interindividual variation in response and adverse drug reactions. This thesis mainly focuses on the variability in erlotinib pharmacokinetics and pharmacogenetics and its association with erlotinib-induced toxicity as well as variability in gemcitabine and carboplatin pharmacogenetics and the association with hematological toxicity.

\section{Inter-individual variability in erlotinib treatment}

There is a large inter-individual variation in response and toxicity in erlotinib treatment due to pharmacokinetic and pharmacogenetic variability. Currently, there is evidence that higher erlotinib plasma concentrations correlate with skin rash and occasionally diarrhea in erlotinib treatment [58-60]. Also, the metabolic ratio, erlotinib/OSI-420, has been associated with skin rash [61] and it has been shown that the erlotinib concentration in the skin at the site of rash is higher compared to nearby unaffected skin [62]. Additionally, skin rash has been suggested to be a biomarker for the response because patients with skin rash tend to have longer progressionfree survival (PFS) and overall survival (OS) [20, 63-65].

\section{Pharmacokinetic variability in erlotinib treatment}

Steady-state plasma trough concentrations of erlotinib are known to vary extensively. The average concentrations at steady-state have been reported to be $800-1600 \mathrm{ng} / \mathrm{mL}$ with a standard deviation of at least half the average concentration [40, 59-61]. Several factors influence the erlotinib concentration and some of them are described below.

Erlotinib is taken as a tablet daily at a recommended dose of $150 \mathrm{mg}$. The tablet should be taken under fasting conditions, either 1 hour before or 2 hours after food intake to avoid the impact of food that increases the bioavailability from the expected $60 \%$ to as much as $100 \%$ [40, 66, 67]. The $\mathrm{AUC}_{0-24}$ has been shown to be higher in patients taking erlotinib 2 hours after food intake compared to taking erlotinib 1 hour before food intake, suggesting that the absorption might be influenced by the different gastric emptying states [66].

The actively transporting enzymes $\mathrm{ABCB} 1$ and $\mathrm{ABCG} 2$ transport erlotinib in vitro $[68,69]$. $\mathrm{ABCB} 1$ and $\mathrm{ABCG} 2$ are expressed for example, in the intestine and act by transporting substrates such as erlotinib back to the intestine $[70,71]$. In a mouse model, the erlotinib bioavailability was increased in the $\mathrm{ABCB} 1, \mathrm{ABCG} 2$, and $\mathrm{ABCC} 1$ knock out mice compared to control [72].

Metabolism of erlotinib is mainly facilitated by enzymes in the CYP family, mostly by $\mathrm{CYP}_{3} \mathrm{~A}_{4}$ but also by $\mathrm{CYP}_{3} \mathrm{~A}_{5}$, CYP1A1 and CYP1A2 [73]. 
Metabolism occurs in the liver as well as outside, for instance, in the intestine by $\mathrm{CYP}_{3} \mathrm{~A}$ and in the lung by CYP1A1 [74]. Erlotinib is metabolized into several metabolites and the main metabolite, OSI-420, is reported to be $12 \%$ of the total erlotinib and to consist of two isomers [40]. Patients who smoke during erlotinib treatment show a lower plasma concentration compared to non-smokers due to the induction of CYP1A1 and CYP1A2 by cigarette smoke [75]. The CYP3A4 enzyme is known to exhibit extensive intraand inter-individual variation influenced by environmental, genetic and physiological factors [76]. The CYP3A activity is, for instance, higher in females compared to males [77, 78]. Co-administration of substances that inhibit or induce $\mathrm{CYP}_{3} \mathrm{~A}$ can also contribute to modulating the erlotinib concentration [79].

Erlotinib is mainly eliminated as metabolites via feces ( $>90 \%$ ), and only a small fraction is eliminated via renal excretion $(<9 \%)$ [74]. Only $2 \%$ of erlotinib is eliminated unchanged.

\section{Pharmacogenetic variability in erlotinib treatment}

Pharmacogenetic parameters have been widely studied to explain the influence of germline variability on exposure, toxicity, PFS, and OS in treatment with erlotinib; however, no consensus regarding the identified SNPs has been reached. The main focus has been on the variability in the emergence of skin rash. These studies have been conducted mainly using targeted approaches, either focusing on the erlotinib target (EGFR) or on erlotinib metabolizing and transporting enzymes, by studying single nucleotide polymorphisms (SNPs) in genes as well as sequencing of entire genes [58, 60, 65, 80-88].

SNPs in the EGFR promoter region and in intron 1 have been shown to influence EGFR expression. In erlotinib treated patients, the promoter SNPs 216G/T (rs712829) and -191C/A (rs712830) have been associated with skin rash $[65,88]$ and diarrhea [58] and the EGFR intron 1 CA repeat has been associated with skin rash [89] and PFS and OS [86].

Genetic variation in $A B C G 2$ at $34 \mathrm{G}>\mathrm{A}$ (rs2231137) and $421 \mathrm{C}>\mathrm{A}$ (rs2231142) are well studied. The $34 \mathrm{G}>\mathrm{A}$ change does not alter the EGFR expression while $421 \mathrm{C}>\mathrm{A}$ is known to lower the expression of ABCG2 [90, 91]. Studies on erlotinib treated patients have identified the $A B C G 2$ SNPs, $-15622 \mathrm{C} / \mathrm{T}$, and $1143 \mathrm{C} / \mathrm{T}$ which are associated with lower ABCG2 expression to correlate with higher plasma concentrations [58], that $34 \mathrm{G}>\mathrm{A}$ is associated with OS [84] and that $421 \mathrm{C}>\mathrm{A}$ is associated with diarrhea [60]. The $A B C B 1$ haplotype $1236 \mathrm{TT}-2677 \mathrm{TT}-3435 \mathrm{TT}$ has been associated with skin rash and with erlotinib plasma concentration [87].

Several metabolizing enzymes have been studied, for instance, have SNPs in CYP27B1 (rs8176345), CYP4F11 (rs1064796) and UGT3A1 (rs10045685) 
have been associated with skin rash and adverse drug reactions in erlotinib treated patients $[81,83]$.

Additionally, an unhypothesized genome-wide association study (GWAS) was performed on never-smoking Asian females diagnosed with adenocarcinoma treated with EGFR-TKIs (mainly gefitinib), suggesting the $4 \mathrm{q} 12$ region to be important for PFS [92].

\section{Pharmacogenetic variability in gemcitabine/car- boplatin treatment}

The pharmacogenetics studies on gemcitabine/carboplatin-induced toxicity have until recently focused on the genetic variability in specific targets in genes involved in the mechanism of action of each drug, for instance, transporters required for the drug to enter the cells, metabolizing enzymes, and DNA repair enzymes. However, the results are contradictory.

One prominently studied gemcitabine related-gene is cytidine deaminase (CDA), which catalyzes the inactivation of most of the administered gemcitabine, and it is known that low CDA activity correlates with a higher response rate, longer time to progression and OS [93]. One of the most frequently studied $C D A$ SNPs, 79A $>C$ (rs2072671), results in a lower CDA activity and lower gemcitabine clearance [94, 95]. Associations with neutropenia have been identified but the results have been contradictory [96100]. Moreover, SNPs associated with hematological toxicity in DNA repair pathways have been extensively studied in several platinum-based chemotherapy combinations [100-105]. These genes are mainly located in the nucleotide excision repair pathway responsible for repairing intra-strand crosslinks. SNPs in ERCC2, IL16, MMS19L, RAD18, XPC, XPD, and XRCC1 have for instance been associated with either hematological toxicity or leukopenia [101, 103, 105-108].

Additionally, a few hypothesis-free GWAS have been performed [109111]. These studies have identified associations with two SNVs protective against platinum induced myelosuppression (rs13014982 and rs9909179) [109] and an additional, four SNVs associated with gemcitabine-induced leukopenia and neutropenia (rs11141915, rs1901440, rs12046844, and rs11719165) [110]. The largest GWAS $(\mathrm{n}=13122)$ included several chemotherapy combinations and identified several SNPs associated with gemcitabine (rs9961113, rs2547917 and rs12900463) and carboplatin (rs11071200, rs3822735 and rs1623879) induced leukopenia and neutropenia [111]. The variants identified in the hypothesis-free approach haven't confirmed the association to regions identified in the knowledge-based candidate approach but rather identified SNPs in regions not previously studied. 
The overall aim of this thesis was to obtain a better understanding of the inter-individual pharmacokinetic and pharmacogenetic variation in patients undergoing NSCLC treatment as well as to identify potential biomarkers for personalized NSCLC treatment.

The specific aims were to:

- Develop an LC-MS/MS method with the ability to quantify erlotinib and its metabolites in order to study pharmacokinetic variability in erlotinib treated NSCLC patients

- Evaluate the $\mathrm{CYP}_{3} \mathrm{~A}$ activity as a potential biomarker in erlotinib treated NSCLC patients

- Study pharmacokinetic and pharmacogenetic variability in erlotinibinduced skin rash and diarrhea.

- Study the influence of genetic variability in ABCG2 on erlotinib transport in vitro

- Study the influence of pharmacogenetic variability in gemcitabine/carboplatin-induced leukopenia and neutropenia. 


\section{METHODS}

In this section, the study populations and methods used in papers I-V are presented and discussed, and more details about the methods are available in the respective papers.

\section{Patient cohorts and study designs}

This thesis includes two studies on NSCLC patients, Table 2. The EM11study included patients with advanced NSCLC treated with the EGFR-TKI erlotinib. Data obtained from the EM11-study were analyzed in papers IIII. The second study included NSCLC patients of mixed stages treated with gemcitabine and carboplatin in either an adjuvant or advanced setting. Data obtained from this study were analyzed in paper V. Both studies were performed after approval by the regional ethics committee in Linköping or Stockholm. Written informed consent was obtained from all patients prior to study entry. 


\section{The EM11-study}

EM11 was a prospective observational study of advanced NSCLC patients, performed between 2013 and 2018 in Linköping, Kalmar, Jönköping, Gävle, and Göteborg. Patients diagnosed with advanced NSCLC scheduled for erlotinib treatment were eligible for inclusion, which led to 65 included patients in the study.

The average age of the study population was 68 years, and $68 \%$ were females and all were diagnosed with adenocarcinoma. EGFR tumor mutations were confirmed in $78 \%$ of the cohort. Among the patients, $5 \%$ were current smokers and $49 \%$ were former smokers. In total, $70 \%$ and $49 \%$ of the cohort experienced skin rash and diarrhea of any grade, respectively.

The study was designed to draw blood samples monthly from the patients in the first three months of treatment and to monitor toxicity up until 12 months of treatment, Figure 2. A sample for extraction of DNA was obtained at baseline. CYP3A activity was assessed before treatment start and after 2 months of treatment. Samples for erlotinib and metabolite plasma trough concentrations were drawn after 1, 2, and 3 months. Drug-induced toxicities, skin rash, and diarrhea were registered monthly up until 12 months of treatment according to CTCAE version 3.0.

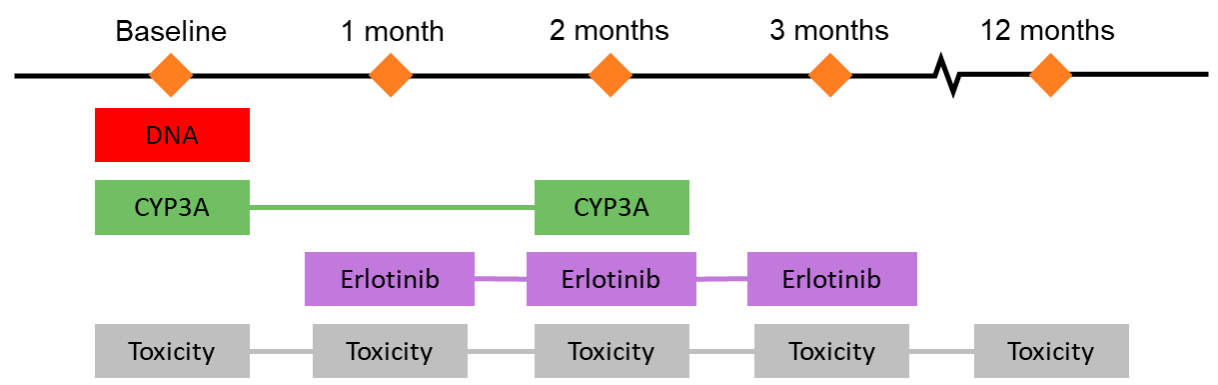

Figure 2: Study design for the EM11-study that was analyzed in papers I-III.

In paper I, erlotinib plasma trough concentrations were analyzed after 1 month of erlotinib treatment in the first included patients $(n=4)$. In paper II, a subset of 32 patients that had provided CYP 3 A activity samples were analyzed. CYP3A activity at baseline and after 2 months of treatment was available in 13 patients, and single point CYP3A activity was available in 19 patients, including 7 at baseline and 12 during treatment. In paper III, the entire study population was analyzed $(n=50$ patients) and 10 patients were excluded due to poor compliance or lack of clinical data and 5 patients were excluded because they were treated with the second-generation EGFR-TKI afatinib. 
Table 2: Overview of the patients included in each paper.

\begin{tabular}{|c|c|c|c|c|c|}
\hline Paper & Therapy & $\begin{array}{c}\text { Number } \\
\text { of patients }\end{array}$ & Time & Centers & Methods \\
\hline $\mathbf{I}$ & Erlotinib & 4 & $2013-2014$ & Linköping & LC-MS/MS \\
\hline II & Erlotinib & 32 & $2013-2016$ & $\begin{array}{c}\text { Linköping } \\
\text { Kalmar } \\
\text { Jönköping } \\
\text { Gävle } \\
\text { Göteborg }\end{array}$ & HPLC \\
\hline III & Erlotinib & 50 & $2013-2018$ & $\begin{array}{c}\text { Linköping } \\
\text { Kalmar } \\
\text { Jönköping } \\
\text { Gävle } \\
\text { Göteborg }\end{array}$ & $\begin{array}{c}\text { LC-MS/MS } \\
\text { HPLC } \\
\text { Genotyping } \\
\text { Gel electrophoresis }\end{array}$ \\
\hline $\mathbf{V}$ & $\begin{array}{c}\text { Gemcitabine/ } \\
\text { Carboplatin }\end{array}$ & 212 & 2006-2008 & Stockholm & $\begin{array}{c}\text { Whole exome } \\
\text { sequencing }\end{array}$ \\
\hline
\end{tabular}

\section{The gemcitabine/carboplatin study}

In paper V, 215 NSCLC patients scheduled for gemcitabine/carboplatin chemotherapy treatment were included in the study in Stockholm between 2006 and 2008. The patients received at least one cycle of gemcitabine on days 1 and $8\left(1,250 \mathrm{mg} / \mathrm{m}^{2}\right)$ and carboplatin on day $1(\mathrm{AUC}=5)$.

The median age of the study population was 64 years, $53 \%$ were females and adenocarcinoma was the most prevalent diagnosis. Among the patients, $43 \%$ were current smokers and $47 \%$ were former smokers. In total, $70 \%$ and $63 \%$ of the cohort experienced leukopenia and neutropenia of any grade, respectively.

The study was designed to draw a blood sample for DNA analysis and to monitor the drug-induced hematological toxicities of neutropenia, and leukopenia at baseline and weekly during the first cycle of 21 days. The nadir values were defined as the lowest leukocyte and neutrophil values measured on days 8,14 , and 21.

Three DNA samples were identified as outliers due to contamination and inadequate sequencing and subsequently removed from the statistical analysis. 


\section{Liquid Chromatography}

Liquid chromatography (LC) methods with fluorescence and tandem mass spectrometry (MS/MS) detection were used in papers I-IV for the determination of $\mathrm{CYP}_{3} \mathrm{~A}$ activity and for quantification of erlotinib and its metabolites, respectively.

In general, the components in an LC instrument include a mobile phase that is continuously pumped through the system to which a sample can be injected $[112,113]$. The sample is transported with the mobile phase to the column where the separation takes place and the separated analytes are then further transported to the detector, Figure 3.

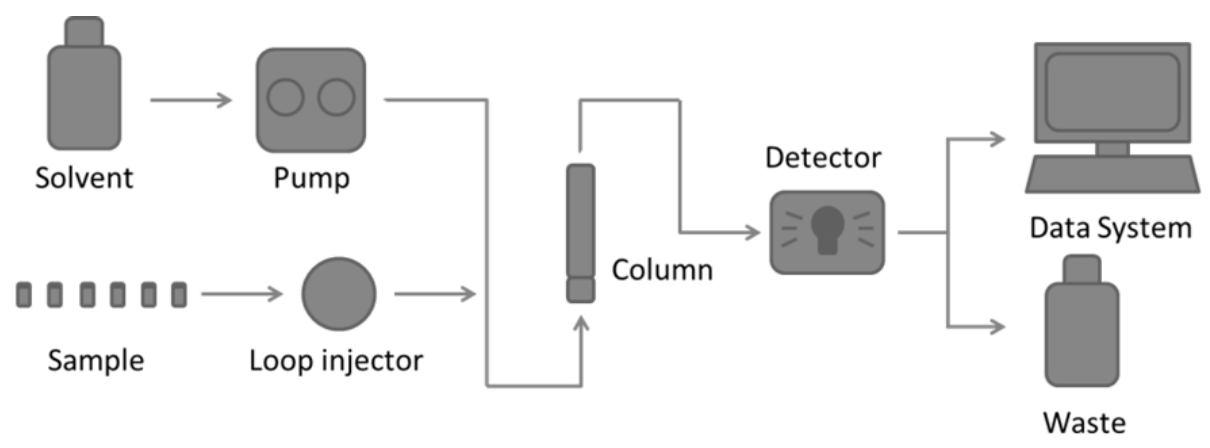

Figure 3: An overview of the included components in an LC system.

The separation of analytes in the column can be based on polarity. In the most common reverse phase chromatography, the column represents the non-polar stationary phase and the mobile phase corresponds to the polar phase $[112,113]$. Substances with similar polarities are drawn together. The metabolites are in general more polar endogenous analytes compared to the main substance and are not as highly attracted to the column. This results in the elution of the metabolites prior to the main substance. The mobile phase is usually applied as a gradient, with increasing concentrations of organic solvent that change the polarity of the mobile phase to become more non-polar, in order to more rapidly elute the main compounds.

Different detectors can be used in combination with an LC system, for instance, UV and, fluorescence detectors and mass spectrometers. Fluorescence detection has greater sensitivity than UV detection but is limited because only a few analytes fluoresce [112]. The analytes are irradiated by a light providing excitation energy and the excited analytes emit light of lower energy that is detected at a $90^{\circ}$ angle to the excitation wavelength. 
The mass spectrometer operates under vacuum and is less dependent on chromatographic separation because the analytes are separated and detected based on mass to charge $(\mathrm{m} / \mathrm{z})$ ratios $[112,114]$. Single gaseous ions are produced by electrospray ionization and directed towards the quadrupoles. The mass spectrometer consists of two quadrupoles, with a varying electric field only allowing ions of the desired parent and daughter $\mathrm{m} / \mathrm{z}$ ratios to pass. Fragmentation takes place between the quadrupoles, as the ions collide with neutral gas molecules, for instance, argon. The signal that is passed through the mass spectrometer is registered by the detector.

\section{Assessment of CYP3A activity}

Both genetic and environmental factors influence CYP3A activity. To determine the real-time $\mathrm{CYP}_{3} \mathrm{~A}$ activity, the phenotype is usually assessed using a probe drug [115]. The probe drug is a substance exclusively metabolized by $\mathrm{CYP}_{3} \mathrm{~A}$ that is monitored in combination with the CYP3A generated metabolite in urine and/or plasma. The acquired ratio between the main substance and the metabolite is utilized as a measure of the CYP3A activity in vivo.

\section{Quinine as a probe for CYP3A activity}

Quinine was the probe drug used in the EM11 study to assess CYP3A activity, as reported in papers II and III. Quinine is hydroxylated only by CYP3A into the metabolite $3-\mathrm{OH}$-quinine, and the metabolic ratio, quinine $/ 3-\mathrm{OH}-$ quinine, is used as a measure of $\mathrm{CYP}_{3} \mathrm{~A}$ activity [116], representing both hepatic and intestinal CYP3A activity [117]. Several other probe drugs are available for determination of $\mathrm{CYP}_{3} \mathrm{~A}$ activity, for instance, oral or intravenous midazolam/1-OH-midazolam [118], or the endogenous CYP3A activity biomarkers cholesterol/4 $\beta$-hydroxycholesterol [119] and cholesterol/6 $\beta$-hydroxycholesterol [120].

In the EM11 study, a tablet of $250 \mathrm{mg}$ of quinine was taken $16 \pm 2 \mathrm{~h}$ before sampling. The quinine/3-OH-quinine ratio has been shown to be stable for 96 hours [116]. Consequently, if the tablet was not taken according to instruction, it is not likely to have an impact on the metabolic ratio. Another advantage of quinine as a biomarker for CYP3A activity is that sampling is only required once.

\section{The HPLC method with fluorescence detection}

An HPLC-method was setup and modified from a previously published article [121]. The method was partially validated for analysis of CYP3A activity in imatinib treated chronic myeloid leukemia patients [122]. The samples were analyzed using an HPLC system with fluorescence detection with 
excitation and emission wavelengths of $350 \mathrm{~nm}$ and $450 \mathrm{~nm}$, respectively, and the analytes were separated on an Xbridge $\mathrm{C} 18$ column at $60^{\circ} \mathrm{C}$. The mobile phase was $0.1 \mathrm{M}$ acetate buffer and acetonitrile, kept at a flow rate of $0.8 \mathrm{~mL} / \mathrm{min}$. The total run time was $12.5 \mathrm{~min}$ and included two linear gradients - from $10 \%$ to $14 \%$ acetonitrile from o to $5 \mathrm{~min}$, followed by $14 \%$ to $26 \%$ acetonitrile from $5 \mathrm{~min}$ to $9.4 \mathrm{~min}$, and finally returning to $10 \%$ acetonitrile from $9.4 \mathrm{~min}$ to $12.5 \mathrm{~min}$. A typical chromatogram is illustrated in Figure 4.

Quinine and 3-OH-quinine were quantified in the range of 100-10,000 $\mathrm{nM}$ and 10-2,000 $\mathrm{nM}$, respectively. Quality control samples were prepared at three concentration levels for quinine $(150,1000$, and 7,500 $\mathrm{nM})$ and $3-$ $\mathrm{OH}$-quinine $(20,150$, and $1,500 \mathrm{nM})$.

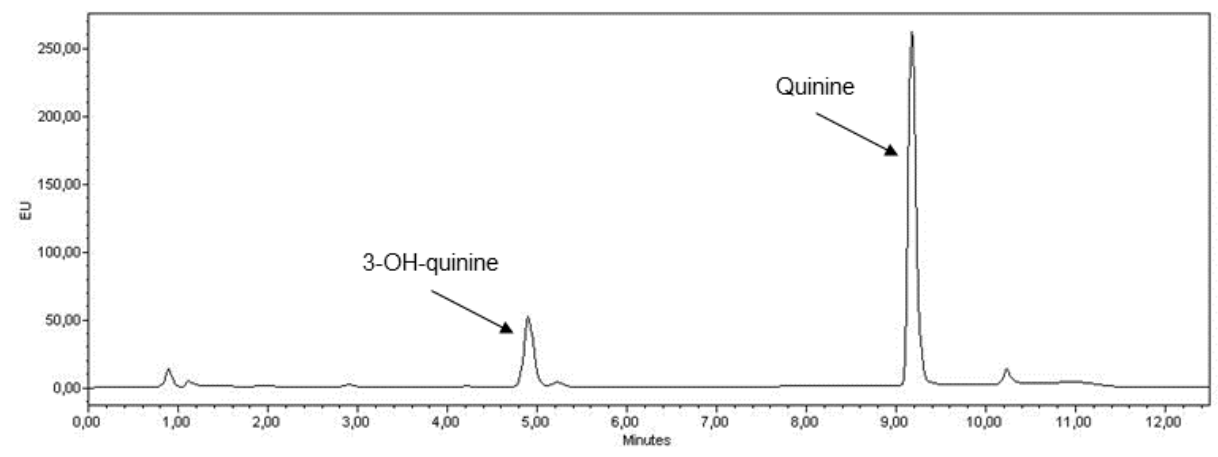

Figure 4: A typical chromatogram showing the peaks of 3-OH-quinine (4.9 min) and quinine (9.1 $\mathrm{min})$.

\section{Quantification of erlotinib and its metabolites}

An LC-MS/MS method for quantification of erlotinib, OSI-420, and didesmethyl erlotinib and for semi-quantification of metabolites was developed in paper I. The method was further used in papers I and III to analyze patient samples and in paper IV to analyze cell lysates.

\section{Metabolite production using human liver microsomes}

Several of the metabolites in this method lacked reference substances and were instead produced using human liver microsomes, Figure 5, which are vesicles from the endoplasmic reticulum in human livers that are prepared by homogenization following differential centrifugation [123]. Phase I metabolism, for instance, hydroxylation by CYP enzymes, can be studied by the addition of the cofactor NADPH. Phase II metabolism can be studied 
by the addition of the cofactor UGDPA to facilitate glucuronidation (addition of sugar molecule) of molecules harboring a hydroxyl group.

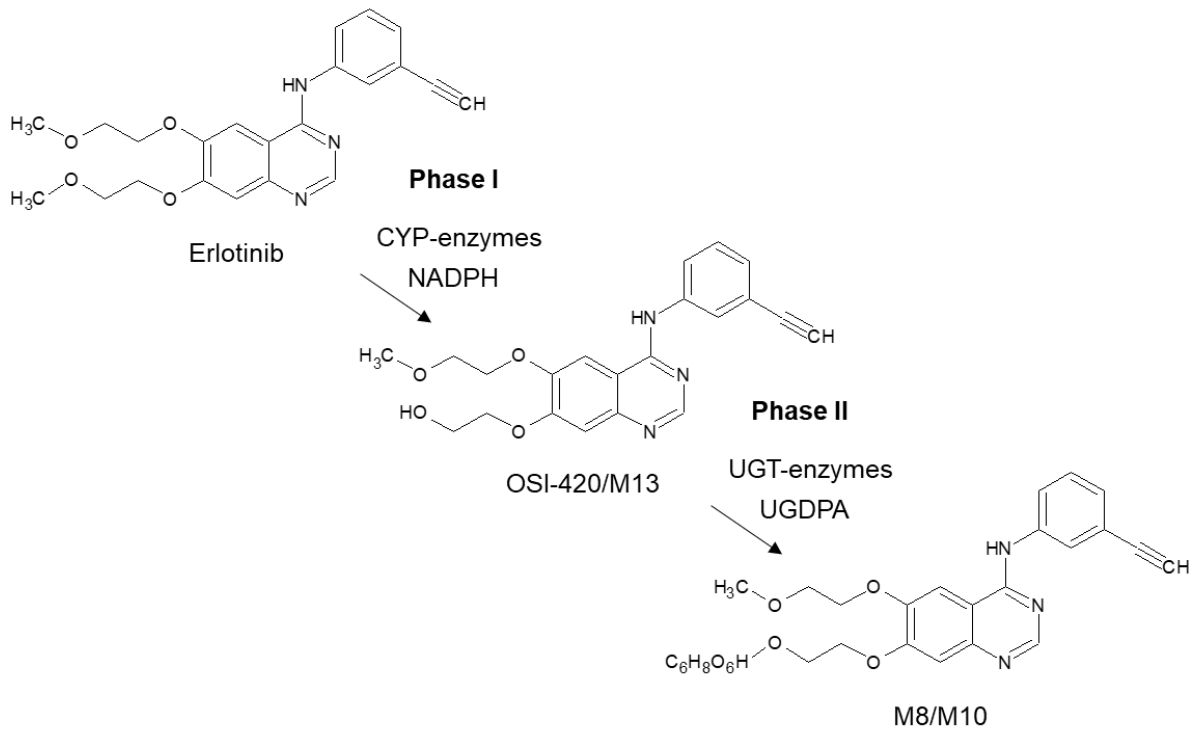

Figure 5: Suggested phase I and phase II metabolism of erlotinib by hydroxylation to OSI-420 or M13 and further glucuronidation to M8 or M10.

\section{The LC-MS/MS method}

Erlotinib and its metabolites were analyzed on an LC-MS/MS instrument, Figure 6 . The analytes were separated on an XBridge $\mathrm{C} 18$ column at $55^{\circ} \mathrm{C}$. The mobile phase was $5 \mathrm{mM}$ ammonium acetate and acetonitrile kept at a flow rate of $0.7 \mathrm{~mL} / \mathrm{min}$. The total run time was $7 \mathrm{~min}$, with a gradient of $10-50 \%$ acetonitrile from o to $5 \mathrm{~min}$, followed by $90 \%$ acetonitrile from 5 min to $6 \mathrm{~min}$ that finally returned to $10 \%$ acetonitrile from $6 \mathrm{~min}$ to $7 \mathrm{~min}$.

The calibration curves were $25-5,000 \mathrm{ng} / \mathrm{mL}, 0.5-500 \mathrm{ng} / \mathrm{mL}$, and 0.15-10 ng/mL for erlotinib, OSI-420, and didesmethyl erlotinib, respectively. Quality control samples at five concentration levels for erlotinib (25, $75,400,1,200$ and 3,750 ng/mL), OSI-420 (0.5, 1.5, 20, 100 and 375 $\mathrm{ng} / \mathrm{mL})$, and didesmethyl erlotinib $(0.15,0.45,1.5,4$ and $7.5 \mathrm{ng} / \mathrm{mL})$ were used.

The method was performed in a positive electrospray ionization mode, and all analytes were monitored by multi-reaction-monitoring. To facilitate the quantification of all analytes in one analysis of $7 \mathrm{~min}$, with average metabolite concentrations around $0.2 \%$ of the average erlotinib concentration, erlotinib was suboptimally quantified using the ${ }^{13} \mathrm{C}$-isotope ion $(\mathrm{M}+1)$ instead of the commonly occurring ${ }^{12} \mathrm{C}$-isotope. This was not enough to achieve a linear calibration curve but erlotinib could be fitted with a 
quadratic curve. This modification solved the initial problem, but it was still a challenge to fit a linear calibration for OSI-420, which can be seen in the inter-batch precision with a lower limit of quantification (LLOQ) of $17 \%$. The reason for the high LLOQ was because the calibration curve tended to be more quadratic than linear.

The metabolites were identified using either a targeted or an untargeted approach. The targeted approach utilized existing literature [124], while the untargeted approach scanned the $200-600 \mathrm{~m} / \mathrm{z}$ range and masses of possible metabolites were further studied in daughter scans. Optimal mass spectrometry settings were identified by stepwise modifications in cone voltage and collision energy. Metabolite structures were suggested based on similarities in fragmentation pattern with already known metabolite structures. The metabolites (M2, M3, M6, M20, M17, M8/M10, M21, M7, M11, M19, M16, and M13) were semi-quantified using the calibration curve from either OSI-420 or didesmethyl erlotinib depending on the metabolite intensities. The semi-quantified metabolites were only validated based on selectivity, precision, and stability. The concentrations obtained from semiquantified metabolites can further only be used for comparison between samples analyzed with this method.
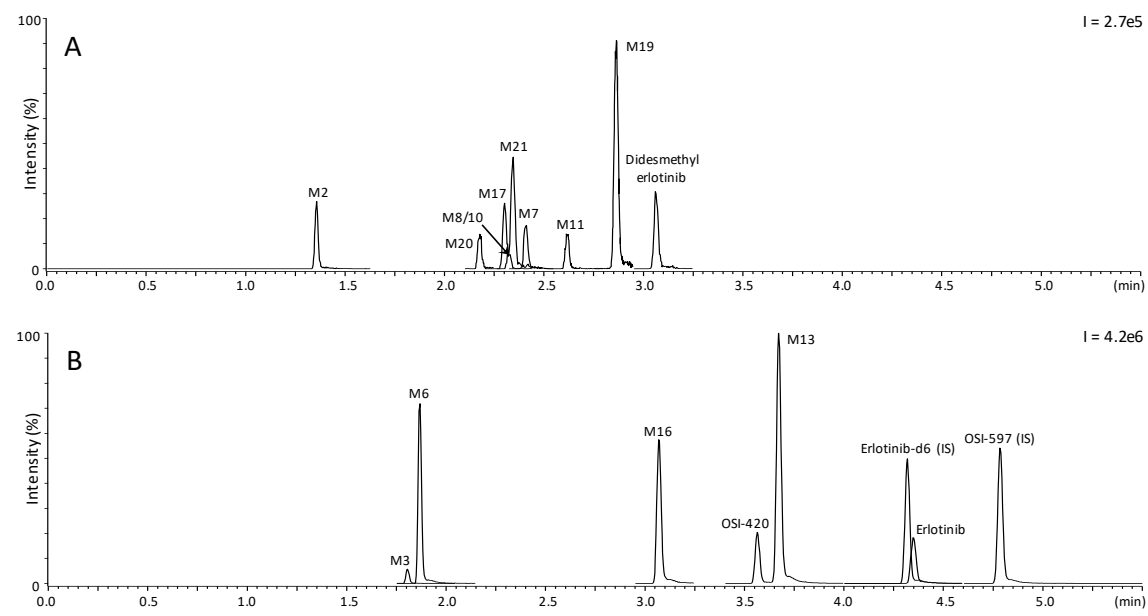

Figure 6: Chromatograms showing metabolites of low intensities (A) and high intensities (B) after a human liver microsome incubation with erlotinib. Figure modified from paper I, figures $2 \mathrm{~B}$ and $2 \mathrm{C}$. 


\section{In vitro studies of $A B C G 2$ mediated erlotinib transport}

In vitro studies were performed in paper IV to study the transport of erlotinib by ABCG2 in the $\mathrm{K}_{562}$ cell line. The $\mathrm{K}_{5} 62$ suspension cell line was developed in 1970 and originates from a 53-year-old female diagnosed with chronic myeloid leukemia [125].

The K562 cell line was considered a suitable model for studies of erlotinib transport because the expression of EGFR and ABCG2 is very low or is absent. Erlotinib is, therefore, unable to exert its antitumoral effect on the $\mathrm{K}_{5} 62$ cells and ABCG2 and ABCG2 polymorphisms can be inserted in the cells to specifically study the transport mediated by the transduced ABCG2.

The two most commonly studied polymorphisms of $A B C G 2-34 \mathrm{G} / \mathrm{A}$ and $421 \mathrm{C} / \mathrm{A}$ - were chosen to be studied in this project. Previously, recombinant cell lines were created using stable retroviral gene transductions [126]. Briefly, vectors containing ampicillin resistance and human wildtype ABCG2 cDNA were grown in Escherichia coli by the addition of ampicillin. The wildtype $A B C G 2$ gene was edited and amplified using PCRbased site-directed mutagenesis with a primer with the point mutation of interest. The edited genes were cut out of the vector and inserted into a retroviral vector (MIY) also containing enhanced yellow fluorescent protein (EYFP) [127]. The packing cell line, 293T, was transfected with MIYABCG2 together with helper vectors VSVG and POL-GAG that are essential for the production of infectious particles. The viral supernatant was used for the transduction of the K562 cell line by spinfection. The MIY vector was randomly integrated into the $\mathrm{K}_{5} 62$ genome and expression of the ABCG2 gene was further mediated by the host.

The established $\mathrm{K}_{5} 62$ cell lines were carriers of wildtype $A B C G 2$, $A B C G 234 \mathrm{G} / \mathrm{A}$, or $A B C G 2421 \mathrm{C} / \mathrm{A}$, and a control cell line only containing an empty MIY vector.

To study differences in erlotinib transport between the differently transduced ABCG2-expressing cell lines, intra-cellular erlotinib concentrations were measured in each cell line after incubation with $1 \mu \mathrm{M}$ of erlotinib for 1 hour. The incubation was stopped by rapidly removing the erlotinib-containing media. Media residues were removed in two washing steps with cold PBS. Different washing conditions were evaluated and the washing method using $5 \mathrm{~mL}$ of cold PBS was selected because the variation between replicates within each cell line were lower compared to when washing with 1.5mL PBS. Washing with $5 \mathrm{~mL}$ PBS did however generate lower erlotinib concentrations, but they were still within the measurable range for the LCMS/MS method. Washing with cold PBS instead of warm PBS additionally 
reduced the variation within the cell lines. The cells were furthers lysed and the proteins were denatured with methanol and ammonium acetate before analysis of the erlotinib concentration using LC-MS/MS.

\section{Assessment of genetic variability by genotyping and sequencing}

\section{Genotyping array}

In paper III, genotyping was performed using an Infinium Global Screening Array BeadChip from Illumina containing 665,608 SNPs [128]. Genotyping with Illumina arrays generally starts with the amplification of genomic DNA [129], followed by fragmentation. The DNA fragments are precipitated before being hybridized to a complementary probe of 50 nucleotides attached to a silica bead on a BeadChip, Figure 7A [130]. Hybridized fragments are extended with a single-base extension method using all four terminator nucleotides. The incorporated nucleotide is detected in a twocolor system of red and green, where ddATP and ddUTP are labeled with dinitrophenyl and ddCTP and ddGTP is labeled with biotin [131]. Dinitrophenyl and biotin are further labeled with red and green fluorescent antibodies, respectively, in a multi-layer immunohistochemical sandwich assay. The bead chip is scanned using an iScan system that creates images of the emitted light from the excited fluorophores, Figure $7 \mathrm{~B}$. Bead intensities are extracted from the image to determine the genotype of each SNP, Figure $7 \mathrm{C}$.
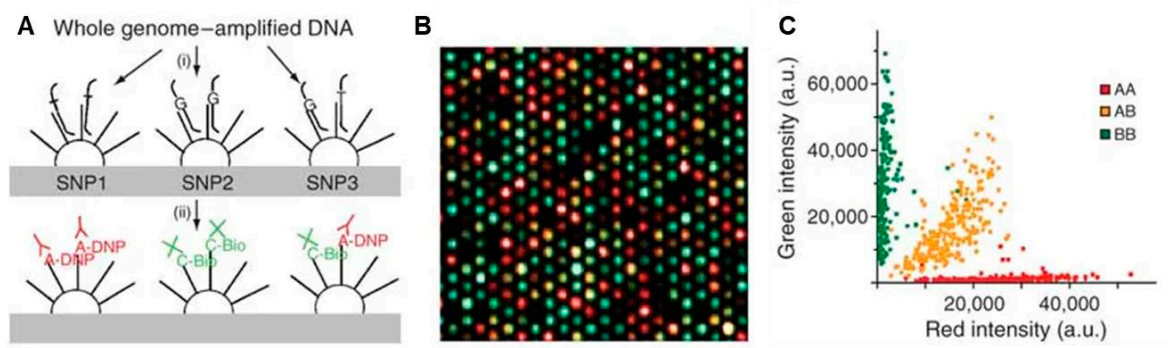

Figure 7: Steps involved in the genotyping assay. (A) Hybridization of DNA fragments to a complementary strand attached to a bead. Extension of the complementary strand by a single base and antibody staining before amplification of the signal. (B) Fluorescent image of the chip. (C) Determination of genotypes based on the red and green intensities. Adapted with permission from Springer Nature: Steemers, F.J., et al., Whole-genome genotyping with the single-base extension assay. Nature Methods, 2006. 3(1): p. 31-33. 


\section{Fragment analysis and capillary electrophoresis.}

In paper III, a dinucleotide repeat in intron 1 of the EGFR gene was analyzed using capillary electrophoresis. Capillary electrophoresis is a technique that separates single-stranded fluorescently labeled DNA-fragments in a polymer-filled capillary [112]. An applied voltage separates the fragments by size. The detector registers the fluorescence and the fragment size is determined by comparing peaks with a simultaneously analyzed ladder with known fragment size as illustrated in Figure 8. Stutter peaks are common in dinucleotide repeats due to slipped strand extension by Taq DNA polymerase during PCR amplification [132].

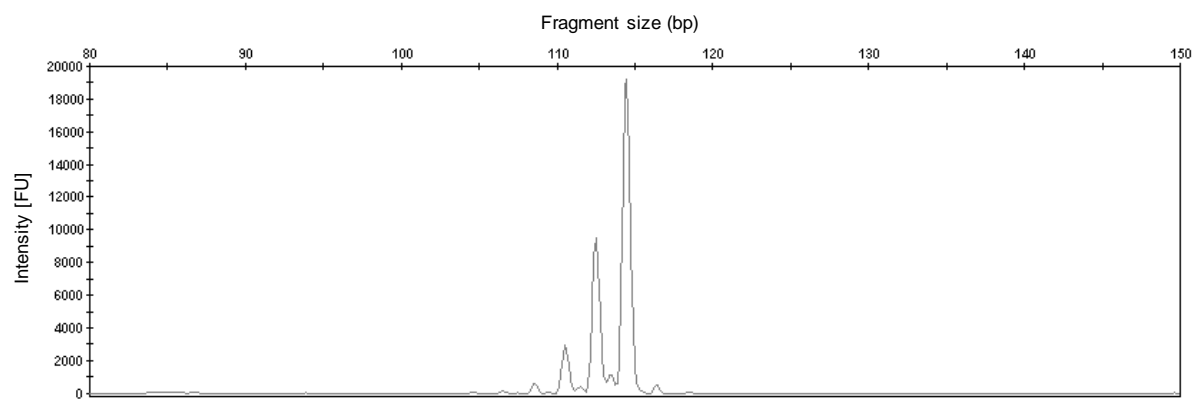

Figure 8: Electropherogram of CA repeats in a homozygous individual.

\section{Sequencing}

Whole exome sequencing was performed in paper $\mathrm{V}$ using the Illumina platform. Illumina short-read sequencing generally starts with enzymatic fragmentation of DNA [133] followed by ligation of adaptors containing different adaptor sequences at each end of the fragment that is being amplified. The fragments are further amplified using solid-phase amplification $[134,135]$, where the fragments are immobilized on a flow cell. The fragments are denatured to single-strand fragments and annealed to a complementary oligonucleotide attached to the surface of the flow cell and amplified. The attached fragments are further amplified by bridge amplification when the adaptor sequence of the attached fragment is ligated to a complementary oligonucleotide on the flow cell creating a bridge that is amplified. This is repeated numerous times to create a cluster of fragments that can be detected in the sequencing reaction.

Sequencing is described as sequencing by synthesis by cyclic reversible termination $[136,137]$. In this process, a DNA polymerase incorporates a single 3'-modified nucleotide labeled with a fluorophore that prevents further incorporation of nucleotides [135]. All four nucleotides, labeled with different dyes, are added simultaneously to the flow cell. Excessive nucleotides are washed away, followed by fluorescence imaging of the flow cell. 
The last step of the cycle involves cleavage and removal of the inhibiting group and the fluorescent dye. The process is repeated a predetermined number of cycles. In order to obtain paired-end sequencing, the flow cell bound fragments are bridged and amplified in order to be able to sequence the complementary strand the same way as the first strand.

A base-calling algorithm determines each nucleotide in a cluster based on the fluorescence image along with a quality score for each nucleotide (Phred score), creating a read from each cluster [138]. By using different software, the reads undergo initial quality control before being mapped to the human reference genome. Aligned reads are further processed before the variants can be determined using variant calling. 


\section{RESULTS \& DISCUSSION}

\section{Chromatography method development}

\section{Quantification of erlotinib and its metabolites (paper I)}

To be able to study erlotinib and its metabolites in plasma in detail, an LCMS/MS method was developed in paper I. The method was used in papers I, III, and IV to analyze patient samples as well as cell lysates. The method was able to quantify erlotinib and the active metabolites OSI-420 and didesmethyl erlotinib as well as to semi-quantify several metabolites. The LC-MS/MS method was validated according to international guidelines from the EMEA and FDA [139, 140].<smiles>C#Cc1cccc(Nc2ncnc3cc(OCCOC)c(OCCO)cc23)c1</smiles>

Figure 9: The structures of the erlotinib metabolite isomers OSI-420 (3.56 min) and M13 (3.67 min). 
The main metabolite has been reported to be around $10 \%$ of the erlotinib concentration [40, 141]. The main metabolite is usually referred to as OSI420; however, it consists of two isomers but they are usually analyzed combined as one analyte, Figure 9. This can be confusing in different publications because this is not always clearly stated. The minor isomer is on average $20 \%$ of the major isomer. In this method, the isomers OSI-420 (minor) and M13 (OSI-413, major), are chromatographically separated and quantified independently, Figure 10, as also described in a previously reported method [141]. The isomers share identical analytical settings and differ only in the retention time. The substance that further on is referred to as OSI-42O is the analyte eluting after $3.56 \mathrm{~min}$, as displayed by the OSI420 reference substance used in paper I, and M13 was subsequently assigned to the analyte eluting after $3.67 \mathrm{~min}$.

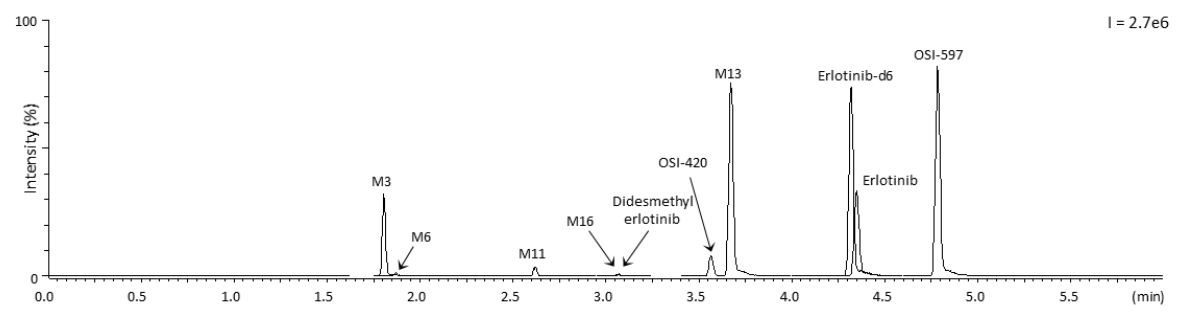

Figure 10: A typical chromatogram from a patient sample after 1 month of erlotinib monotherapy. The figure has been modified from paper I, Figure 1C.

Several quantification methods with different advantages are available for quantification of erlotinib alone [142-144], quantification of erlotinib and one or two metabolites [141,145-149], or quantification of erlotinib in combination with other EGFR-TKIs [150-154]. The advantage of this particular method is that it is relatively broad with the ability to quantify erlotinib, to quantify and separate the main metabolites OSI-42O and M13 as well as quantify didesmethyl erlotinib and semi-quantify several more metabolites. The drawback of the method is that the analysis time of $7 \mathrm{~min}$ is longer than many other methods. 


\section{Erlotinib in vitro}

\section{ABCG2 transport (paper IV)}

In paper IV, the influence of genetic variability in ABCG2 on the intra-cellular erlotinib concentration was studied in the $\mathrm{K}_{562}$ cell lines. The two common $A B C G 2$ SNPs - 34G $>\mathrm{A}$ and $421 \mathrm{C}>\mathrm{A}$ - and the wild-type $A B C G 2$ were compared with a control cell line containing an empty plasmid without ABCG2 expression. The $\mathrm{K}_{5} 62$ cell line was a convenient model to use for intra-cellular concentration studies because the $\mathrm{K} 562$ naturally has very low levels or not at all express ABCG2 or EGFR (www.proteinatlas.org) [155].

The genetic variant $421 \mathrm{C}>\mathrm{A}$ has generally been associated with low ABCG2 expression [91, 156] and no difference in erlotinib intra-cellular concentrations was previously observed between a cell line harboring $421 \mathrm{C}>\mathrm{A}$ and the control cell line without ABCG2 [68], which was confirmed in our K562 model, Figure 11.

Intra-cellular erlotinib concentrations

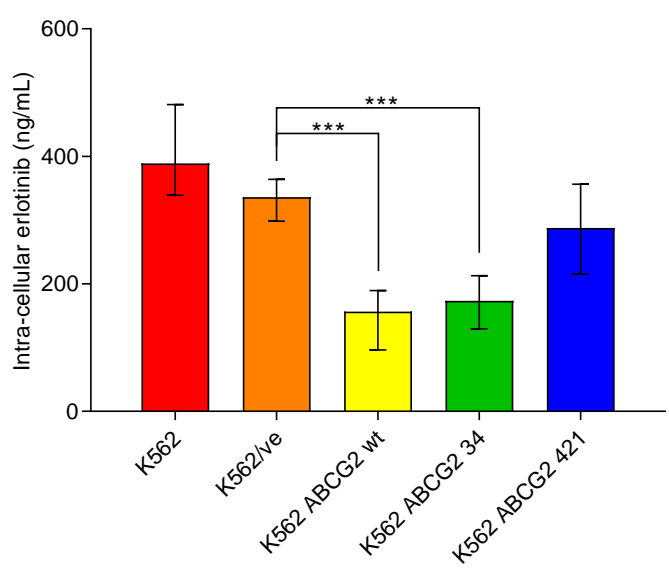

Figure 11: Intra-cellular erlotinib concentrations. Differences in mean erlotinib intra-cellular concentrations evaluated using one-way ANOVA with the Tukey HSD post-hoc test. Note: ${ }^{* * *} \mathrm{p} \leq 0.001$. Modified figure from paper V, Figure $3 \mathrm{~A}$.

The transport of erlotinib by ABCG2 harboring the genetic variant $34 \mathrm{G}>\mathrm{A}$ was previously unknown; however, the $34 \mathrm{G}>\mathrm{A}$ has generally been shown to possess similar transport activity as wild-type ABCG2 [91]. This was also observed in our experiments, and the $34 \mathrm{G}>\mathrm{A}$ variant showed reduced intracellular concentrations of erlotinib similar to wild-type ABCG2, Figure 11. When taking differences in ABCG2 expression into account, the $34 \mathrm{G}>\mathrm{A}$ 
variant was able to transport more erlotinib with a lower expression of ABCG2 on the cell surface. This finding should, however, be viewed with caution because this might be due to limitations in the modeling system.

Other limitations of this study were that the cell experiments were only carried out in one cell line and only at a concentration of $1 \mu \mathrm{M}$, which is at the lower end of the clinically relevant concentration interval.

\section{Erlotinib pharmacokinetics in vivo}

In the EM11 study presented in paper II and III, erlotinib-induced diarrhea was found to be associated with erlotinib and M13 exposure. Skin rash, on the other hand, was associated with $\mathrm{CYP}_{3} \mathrm{~A}$ activity and erlotinib and metabolite ratios, including the metabolite OSI-420. Males experienced more severe skin rash than females and this might be linked to reduced CYP3A activity in males compared to females.

\section{Gender differences (paper III)}

The severity of erlotinib-induced skin rash was shown to differ between the genders in paper III, which has also been reported previously [61], and males were found to experience more severe skin rash compared to females, Figure 12. Diarrhea displayed no gender differences, and was instead, influenced by age.

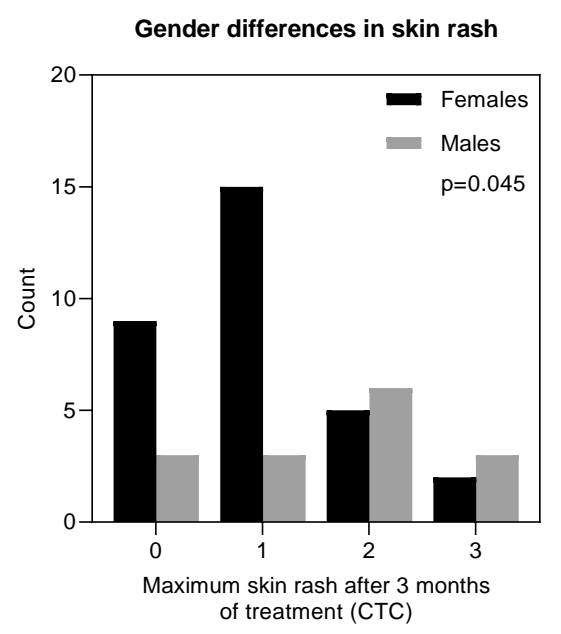

Figure 12: The severity of maximum skin rash (CTC) split by gender after 3 months of erlotinib treatment (Fisher's exact test). 


\section{Erlotinib plasma trough concentrations (paper III)}

Previously reported average plasma concentrations of erlotinib in European patients after 1 month of treatment have been reported to be 700$1,300 \mathrm{ng} / \mathrm{mL}[59,61]$, which is in line with the average result after 1 month in this study $(1,083 \mathrm{ng} / \mathrm{mL})$. Tiseo et al. (2015) also measured the erlotinib concentration after 1 week of treatment, showing that the average concentration was almost twice as high compared to after 1 month of treatment [59].

In paper III, the exposure of erlotinib and a metabolite was found to be associated with diarrhea. The concentration of erlotinib and the major metabolite M13 both correlated to diarrhea after 1 and 2 months of treatment and suggestively after 3 months of treatment. Trends towards an association with diarrhea were also observed for the concentration of didesmethyl erlotinib and M6. Also, when summarizing all active analytes, a suggestive association was observed after 2 and 3 months.

Previous studies have mostly shown no correlations between erlotinib exposure and diarrhea $[58,157,158]$, but one study has [60]. For other EGFR-TKIs such as afatinib and osimertinib, correlations between diarrhea and drug exposure have been observed [159, 160].

The mechanism behind EGFR-TKI-induced diarrhea is yet to be determined, but several different mechanisms or combinations of mechanisms have been proposed, for instance, dysregulated ion transport, inflammation, and mucosal injury [50-52].

\section{CYP3A activity (paper II and III)}

$\mathrm{CYP}_{3} \mathrm{~A}$ is the major metabolizer of several xenobiotics as well as of erlotinib [73], and its activity can vary 40-fold [161]. In paper II, CYP3A activity was found to be induced during treatment, generating a lower quinine metabolic ratio compared to the ratio at baseline, Figure 13A. Trends pointing in that direction have previously been reported [59, 162], and our findings thus complicate the use of baseline CYP3A activity as a possible biomarker during treatment. Also in paper II, females were shown to have higher CYP3A activity compared to males, Figure 13A, as previously identified [78, 163].

In paper III, additional clinical data from the EM11 study were added and the association of CYP3A activity with erlotinib pharmacokinetics and toxicity was investigated. No correlations were identified between baseline CYP3A activity and erlotinib pharmacokinetics or toxicity, probably due to the previously identified induction. 


\section{CYP3A activity in erlotinib treated NSCLC patients}
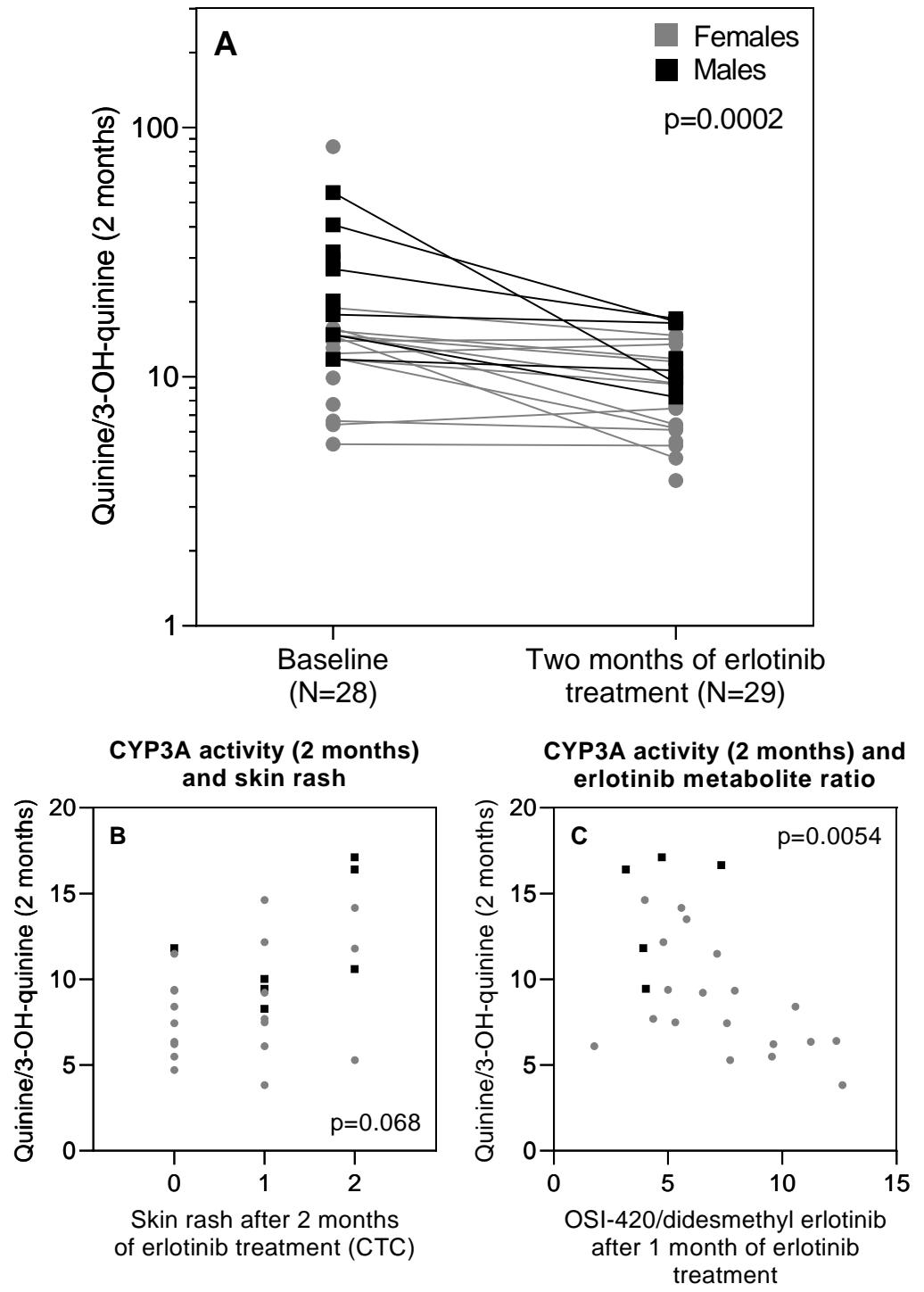

Figure 13: Figure modified from papers II and III, illustrating associations identified with $\mathrm{CYP}_{3} \mathrm{~A}$ activity highlighting differences between females (grey) and males (black). (A) Induction of CYP3A activity was observed after 2 months of treatment as well as gender differences in $\mathrm{CYP}_{3} \mathrm{~A}$ activity (Mann-Whitney Utest). (B) Lower CYP3A activity was seen in patients with an increased grade of skin rash (Kruskal-Wallis test). (C) A correlation was identified between $\mathrm{CYP}_{3} \mathrm{~A}$ activity and the erlotinib metabolite ratio OSI-420/didesmethyl erlotinib (nonparametric correlations). 
The CYP3A activity after 2 months of erlotinib treatment was suggestively associated with skin rash, Figure 13B. CYP3A activity was also associated with erlotinib and metabolite ratios erlotinib/OSI-420, M13/OSI-420, and OSI-420/didesmethyl erlotinib at one or more time points during erlotinib treatment, Figure 13C. Steffens et al. (2016) previously showed that the ratio of erlotinib/OSI-420 best explained the severity of skin rash [61]. It should be noted that OSI-420 in Steffens et al. (2016) includes both isomers, which correspond to OSI-420 and M13, in our data. Erlotinib/(OSI$420+\mathrm{M} 13$ ) was not found to be associated with skin rash in our study but was suggestively associated with $\mathrm{CYP}_{3} \mathrm{~A}$ activity.

Several studies have shown that higher erlotinib plasma trough concentrations correlate to skin rash $[59,61]$. A possible reason why this was not observed in our data could be due to the small sample size. The time of sampling could also be an additional explanation. Tiseo et al. 2015, showed that average erlotinib plasma concentrations were almost twice as high after 1 week compared to 1 month of erlotinib monotherapy, and the association between skin rash and erlotinib concentration was identified after 1 week of treatment [59]. Erlotinib is expected to reach a steady-state within 8 days and a possible explanation as to why the erlotinib concentration is higher after 1 week compared to 1 month of erlotinib treatment could be that the $\mathrm{CYP}_{3} \mathrm{~A}$ activity has not yet been significantly induced at the earlier time point. Because skin rash previously has been correlated to erlotinib exposure several times, patients with interrupted treatment prior to the first sampling time may have had a higher erlotinib plasma concentration compared to those that did not discontinue their treatment due to toxicity in this study. Additionally, the gender differences in skin rash observed in this study could potentially be a result of the differences in CYP3A activity between females and males.

In summary, the pharmacokinetic data from the EM11 study showed that erlotinib-induced diarrhea was associated with erlotinib and M13 exposure while skin rash was associated with $\mathrm{CYP}_{3} \mathrm{~A}$ activity and erlotinib and metabolite ratios including OSI-420. 


\section{Pharmacogenetics in NSCLC}

\section{Erlotinib-induced skin rash and diarrhea (paper III)}

Paper III studied the genetic variability associated with erlotinib induced skin rash and diarrhea. In total, 171 SNPs located in the EGFR, CYP3A4, $C Y P_{3} A 5, A B C G 2, A B C B 1, C Y P_{2} B_{1} 1, P I K_{3} C A$ and $A K T 1$ passed the quality control. The genes were selected because one or more SNPs in these genes were previously found to be associated with skin rash or diarrhea $[58,60$, $65,82,83,86-88]$.

Only SNPs associated with skin rash were identified after the analyses. The rs10856870 in ABCG2 was associated with skin rash after 1, 2 and 3 months of treatment and the association was after 1 month of treatment still significant after multiple corrections $(\mathrm{p}=0.040)$, Figure 14. Additionally, three $A B C G 2$ intronic SNPs (rs2904185, rs75048878 and rs2127863) were identified to be associated with skin rash ( $\mathrm{p}<0.05$ at all time points). There is no previous knowledge about the rs10856870 intron SNP; however, other SNPs in $A B C G 2$ influencing the expression and activity of ABCG2 have previously been associated with increased plasma concentration [58], response and OS [84] and gefitinib induced skin rash [164].

ABCG2 (rs10856870)
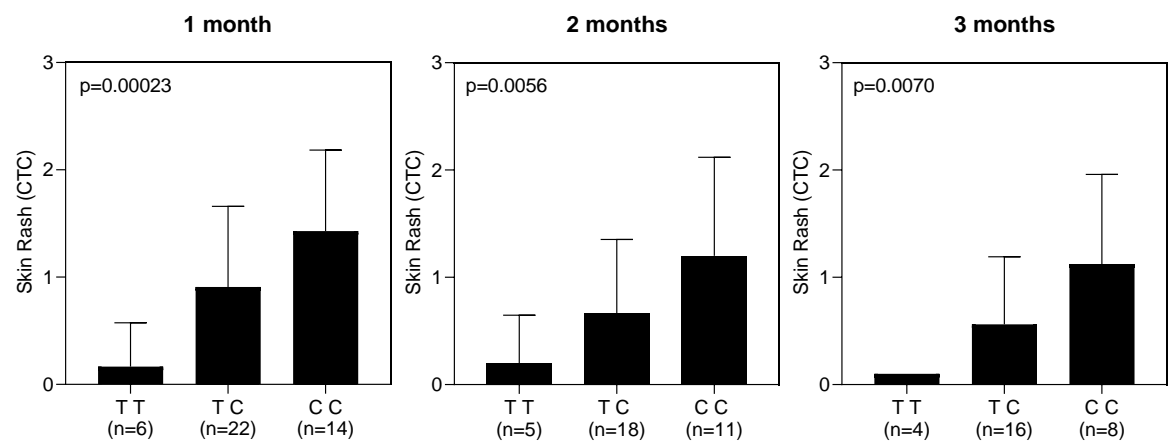

Figure 14: The SNP rs10856870 in ABCG2 was associated with skin rash after 1,2 , and 3 months of treatment, showing the TT genotype to be protective against skin rash. The bars represent the mean $+\mathrm{SD}$.

After 2 and 3 months of erlotinib treatment, SNPs in $A B C B 1$ and $C Y P 27 B 1$ were associated with skin rash. The correlations to SNPs in $A B C B 1$ and $C Y P 27 B 1$ could first be identified after 2 months of treatment and the correlation became clearer after 3 months. After 3 months of treatment, the SNPs were suggestive of association after multiple corrections. These 
findings might be influenced by the reduced number of patients in the analysis further on into the treatment or related to the induction of CYP3A activity.

\section{Gemcitabine/carboplatin induced leukopenia and neutropenia (paper V)}

Paper V studied the genetic variability associated with gemcitabine and carboplatin induced leukopenia and neutropenia, Figure 15. In total, 71,374 variants (minor allele frequency (MAF) > 0.01), located in or near a gene passed the quality control and were used in the statistical analysis. The decrease in leukopenia and neutropenia - as the nadir values normalized to baseline - was the studied phenotype during the first treatment cycle.

The currently available studies on chemotherapy-induced hematological toxicity have usually determined the phenotypes leukopenia and neutropenia slightly different from what was performed in paper V. In common for all studies is that the leukocyte and neutrophil counts have been analyzed to generate a quantitative value that is not subjected to interpretation or evaluation by different individuals. In paper V, the continuous leukocyte and neutrophil values adjusted for the respective baseline values were used in the statistical analyses instead of categorizing the blood status according to the CTCAE grading system before analysis. The choice to use the decrease phenotype was made based on the observation that the lowest FDR rate was achieved when adjusting for baseline values compared to only using the nadir alone. The FDR signal was most prominent for the decrease in leukopenia. Another difference between paper $\mathrm{V}$ and previous studies was when in time of the chemotherapy cycle the blood sampling was performed, which usually was performed at the beginning of a new treatment cycle; however, in paper $\mathrm{V}$, the blood status was monitored weekly and only during the first cycle. The blood status measurement that was assigned the nadir value in paper $\mathrm{V}$ was usually the leukocyte or neutrophil count determined after 1 or 2 weeks. Because this study only covers hematological toxicity during the first cycle in order to identify which patients were at risk of leukopenia and neutropenia, the phenotype used in paper $\mathrm{V}$ also differs from others studies that have studied the lowest CTC grade experienced from all treatment cycles or the time it takes to reach a predetermined CTC grade [110, 111].

No single variants passed multiple corrections after the association analyses, which could be an indicator that the effect of a single variant could not explain the severity of leukopenia or neutropenia and that more than one variant might contribute to the observed variation in toxicity. A p-value cut-off was determined, based on where the false discovery rate was the lowest in order to obtain variants with a suggestive association. To combine the small effects of several variants, variants residing in genes were merged 
into gene sets, and gene-based tests were performed. The gene-based tests showed that two leukopenia-associated genes - SVIL and EFCAB2 passed multiple corrections.

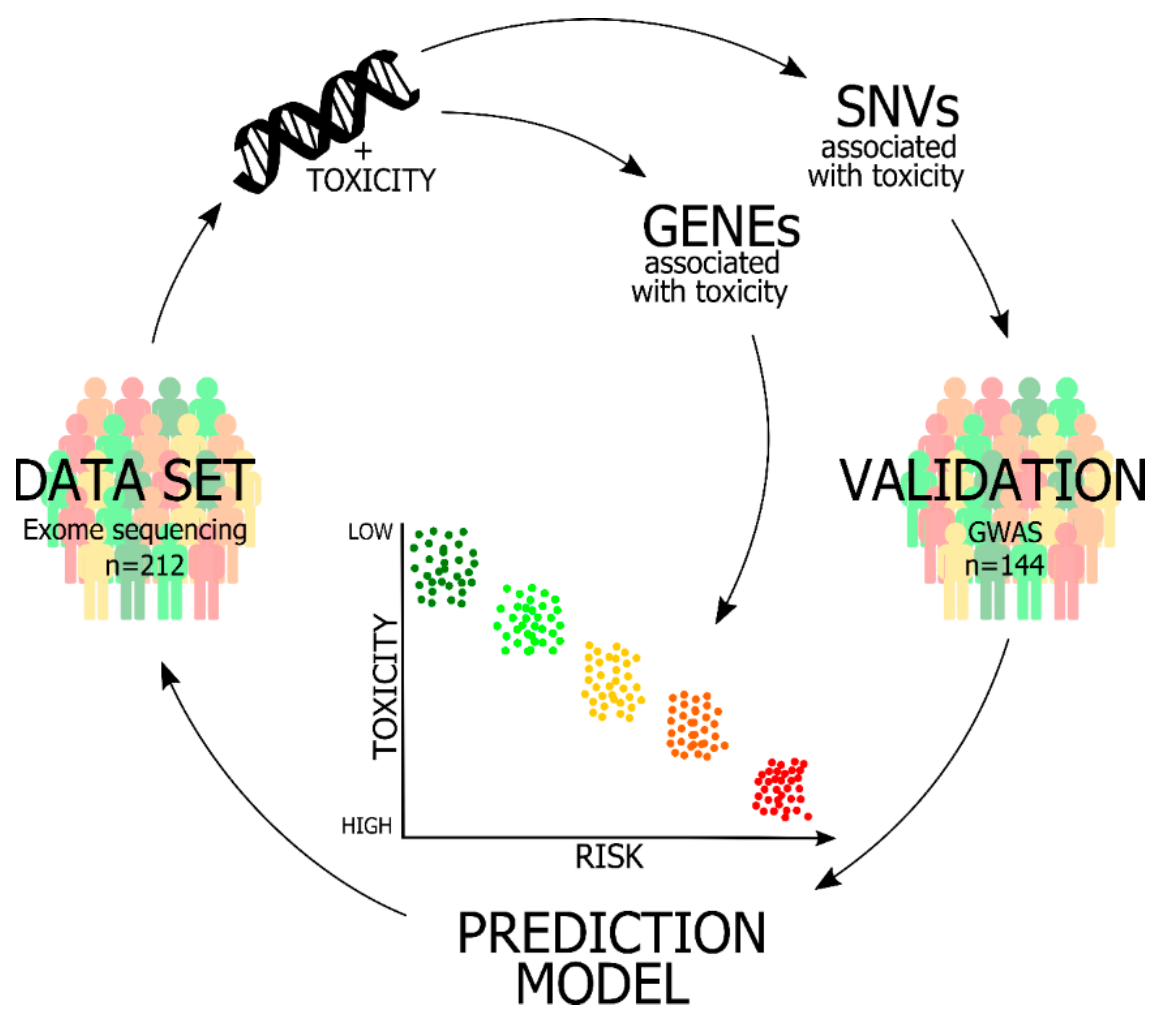

Figure 15: An overview of the whole-exome sequencing study. Variants and genes associated with leukopenia and neutropenia were identified, and the variants were validated using an external GWAS data set. Validated variants, variants in genes and variants were merged in a weighted genetic risk model.

Due to the lack of validation data, the results from a GWAS were used to study linkage disequilibrium between top hit SNPs. The validation data originated from a study on ovarian and lung cancer patients treated with paclitaxel and carboplatin. Subsequently, the choice of validation data was not ideal because the GWAS analyzes tag-SNPs which are usually intronic SNPs, and the whole exome covers the coding regions. To overcome the fact that the positions of the top hit variants in each data set did not agree, the pair-wise linkage disequilibrium was studied between exome-sequenced top hits and GWAS associated top hits. Because carboplatin is the drug that our NSCLC cohort and the validation cohort had in common, the variants 
that could be suggestively validated could only be linked to carboplatin-induced leukopenia or neutropenia. The influence of gemcitabine-induced leukopenia and neutropenia could not be validated. The validation could verify a few SNPs associated with leukopenia and neutropenia, for instance, two SNPs in EFCAB2 and three SNPs in SVIL were suggestively validated.
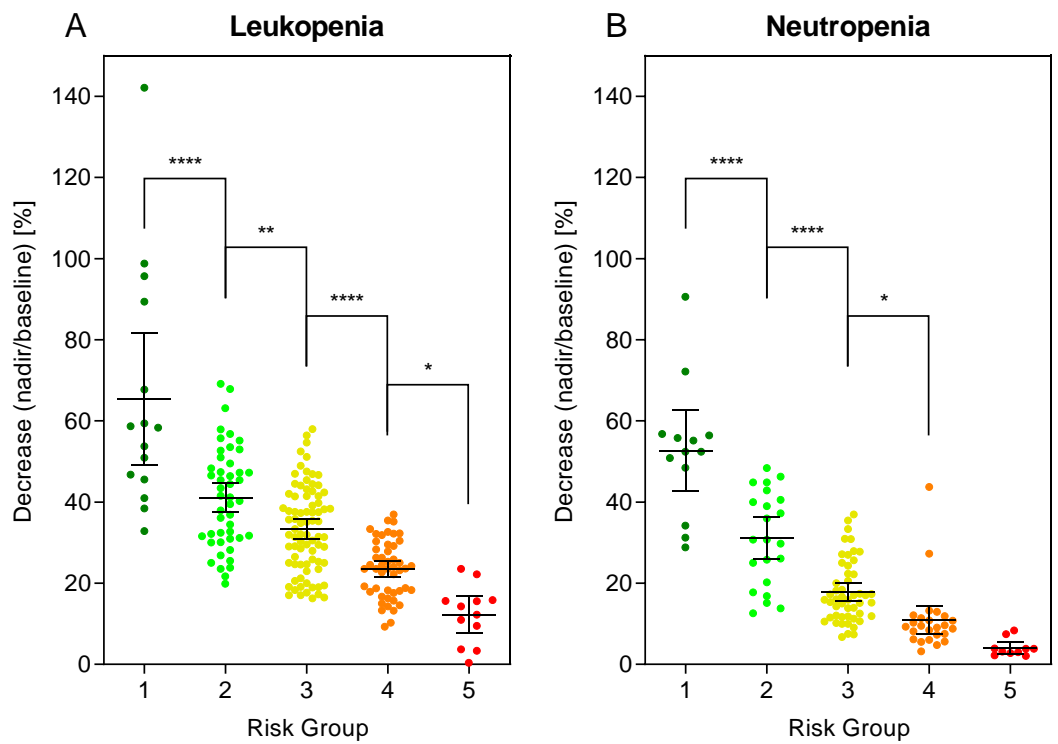

Figure 16: The weighted genetic risk model applied to the exome sequenced data set and illustrated using the untransformed decrease phenotype (ANOVA with Sidak's multiple comparisons test). Error bars illustrate the mean $\pm 95 \%$ CI.

To utilize the small effect from several variants, two prediction models based on weighted genetic risk scores were created, one for each phenotype. Variants from the validation, from the gene-based and single-variant association analyses, were merged into one model, Figure 16. The models showed that the average decrease in leukocytes and neutrophils were statistically different between all risk groups except for neutropenia between the risk group 4 and 5 . 


\section{CONCLUSIONS}

In conclusion, the results from papers $\mathrm{I}-\mathrm{V}$ indicate that pharmacokinetic and pharmacogenetic variability has an influence on the inter-individual variation observed in NSCLC patients.

More specifically from the in vitro erlotinib experiments and the EM11study, we can conclude the following:

- Erlotinib transport was influenced by genetic variation in the ABCG2 gene in vitro

- $\mathrm{CYP}_{3} \mathrm{~A}$ activity was induced in erlotinib treated patients after 2 months of erlotinib treatment.

- Skin rash was associated with CYP3A activity and CYP3A activity was associated with the erlotinib metabolic ratio OSI-420/didesmethyl erlotinib. Skin rash was also associated with the ABCG2 SNP rs10856870.

- Erlotinib-induced diarrhea correlated with erlotinib and metabolite M13 exposure.

- Males experienced more severe skin rash compared to females. 
From the gemcitabine/carboplatin study we can conclude the following:

- Genetic variants and genes were found to be associated with leukopenia and neutropenia.

- Variants were suggestively validated using an external GWAS dataset.

- Risk prediction models for leukopenia and neutropenia based on weighted genetic risk scores created by the use of the cumulative effect of several genetic variants showed a difference in the mean decrease parameter between the risk groups.

The findings in this thesis need to be further validated in order to establish their clinical relevance. 


\section{FUTURE ASPECTS}

In the EM11 study, CYP3A activity and genetic variability were found to be important for the occurrence of skin rash, and the erlotinib and M13 exposures were important for diarrhea. Validation of these findings in a larger study would be of great interest in order to determine the usefulness of these findings in personalized erlotinib treatment.

To further understand the role of CYP3A activity in erlotinib treatment, it would be of interest to follow the induction of CYP3A activity more closely, at several times points during the first two months of treatment and if possible using an endogenous $\mathrm{CYP}_{3} \mathrm{~A}$ activity probe, while also further exploring the gender differences.

To further improve treatment with erlotinib and other EGFR-TKIs, it would be of interest to keep track of steady-state plasma concentrations of erlotinib and its metabolites in patients in order to ensure that adequate erlotinib concentrations are reached, perhaps by using therapeutic drug monitoring. This is especially the case early in treatment when toxicities usually arise and after dose adjustments. Routine monitoring could be combined with toxicity reporting in order to establish reliable concentration intervals for the patients to ideally reside within. This could generate more efficient erlotinib treatment since treatment with erlotinib only is possible during a limited time due to the development of resistance by the tumor. The separation of the isomeric metabolites has shown that the 
metabolites are linked to different toxicities, ratios of OSI-420 showed association to CYP3A activity while M13 correlated to diarrhea, which supports that the metabolites should be determined separately.

In a larger erlotinib study, it would be of interest to identify the patients who are at risk of early treatment discontinuation due to toxicity. Unfortunately, the majority of these patients only provided baseline samples in the EM11-study. Closer monitoring of CYP3A activity and erlotinib and metabolite concentrations early on in the treatment could possibly explain why these patients discontinue their treatment. One way to avoid discontinuation and severe toxicities would be to start all patients at a lower dose, which in combination with therapeutic drug monitoring of erlotinib could be used to adjust the dose in order to reach adequate concentrations. This would also allow the CYP3A activity to adapt to the treatment.

Additionally, the genetic variability should be taken into account because the SNPs identified in the EM11 study were found in genes associated with the transport of erlotinib such as ABCG2 and ABCB1. Genetic variability in ABCG2 was additionally shown to influence the transport of erlotinib in vitro. The successful personalization of erlotinib treatment will most likely include combining both pharmacokinetic and pharmacogenetic parameters.

In the gemcitabine/carboplatin study, pharmacogenetic information from a whole-exome sequencing study was used to build two prediction models. The model utilizes the cumulative effect of several genetic variants to foresee the severity of the reduction of leukocytes and neutrophils during gemcitabine/carboplatin treatment. It would be of interest to further develop and refine the models, perhaps by the addition of other clinical parameters. It would also be interesting to validate the models in a larger data set in order to prove their clinical benefit. 


\section{ACKNOWLEDGMENTS}

Det finns många som på ett eller annat sätt har bidragit till att den här avhandlingen har blivit av. Tack för att ni har gjort de här åren så intressanta och givande! Jag vill rikta ett speciellt tack till följande:

Mina handledare: Huvudhandledare Henrik Green, tack för att du gett mig förtroendet att arbeta med dessa intressanta projekt, din oändliga optimism och kunskap som du delat med dig av. För att du alltid tar dig tid för mina projekt även om du har mycket inplanerat i ditt schema. Svante Vikingsson, tack för att du delat med dig av dina kunskaper och erfarenheter inom kromatografi och fick mig att fundera på doktorandspåret. Joakim Lundeberg, tack för att du delat med dig av din otroliga kunskap inom genetik och optimism.

EM11-studien: Jag vill rikta ett stort TACK till alla patienter och deltagande studiecenter, läkare och forskningssjuksköterskor, som gjort EM11studien möjlig. Anders Vikström, Gunilla Kaldenberg, Niels Hornstra, Anna Ellin, Magnus Kentson, Louise Hellberg, Eva Brandén, Hirsh Koyi, Lise-Lotte Sundgren, Bengt Bergman och Marie Roth. Ni och era kollegor gör ett fantastiskt jobb! 
Co-authors: Thank you for great collaborations, Benjamín Sigurgeirsson, Sailendra Pradhananga, Rolf Lewensohn, Luigi De Petris, María Apellániz-Ruiz, and Cristina Rodríguez-Antona. Lianne Jacobs, I'm incredibly grateful that you came to Linköping and shared your laboratory skills in experiments on erlotinib with me.

Forum Scientium och Stefan Welin Klintström, tack för att jag har fått deltagit på intressanta seminarier, studiebesök och sommarkonferenser.

Kontoret: Tack Niklas Björn, Ingrid Jakobsen, Anna Zimdahl, Lucia Pellé, Anna Åstrand, Gerd Jakobsson och Mattias Persson för att ni har bidragit till en superbra arbetsmiljö på kontoret, givande diskussioner och för att ni delar med er av er kunskap. Jag uppskattar att ni har haft överseende med mitt organiserade kaos. Det är med glädje jag går till jobbet.

Tidigare och nuvarande kollegor. Tack för trevliga fikastunder och diskussioner! Tack för att ni har engagerat er i att lösa mina problem när allt inte går som planerat på labb. Tack Louise Karlsson, Andreas Ärelman och Björn Carlsson för att ni låter mig dela massen med er och för all hjälp när något krånglar.

Syjuntan, Anna Jönsson, Yvonne Lood och Sara Gustavsson, tack för alla pysselstunder och att ni har lärt mig att det finns så många fler material man kan pyssla med än just tyg.

Vi hinner inte ses så mycket nu för tiden, men när vi ses så känns det som att det var igår. Maria och Helena. Therese, tur för mig att det finns fler som aldrig tröttnar på tacos.

Jag vill tacka min familj, mamma Ingela och pappa Ulf för att ni alltid finns där och stöttar oavsett vad jag tar mig för. Lina för att du är en toppensyrra som ser till att jag inte glömmer några födelsedagar och skämmer bort oss när vi mellanlandar på väg hemhem. Calle, tack för att du är så fantastisk och drar det tunga lasset när jag har mycket att göra. Jesper och Anton, tack för att ni förgyller vardagen med er otroliga energi och glädje! Dexter och Vera, tack för alla keliga stunder. 


\section{REFERENCES}

1. Siegel, R.L., K.D. Miller, and A. Jemal, Cancer statistics, 2019. CA Cancer Journal for Clinicians, 2019. 69(1): p. 7-34.

2. Ferlay J, E.M., Lam F, Colombet M, Mery L, Piñeros M, Znaor A, Soerjomataram I, Bray F. Global Cancer Observatory: Cancer Today. Lyon, France: International Agency for Research on Cancer. Available from: https://gco.iarc.fr/today. 2018 [cited 2019. Nov 25].

3. Malhotra, J., et al., Risk factors for lung cancer worldwide. European Respiratory Journal, 2016. 48(3): p. 889-902.

4. McKay, J.D., et al., Lung cancer susceptibility locus at 5p15.33. Nature Genetics, 2008. 40(12): p. 1404-1406.

5. $\quad$ Thorgeirsson, T.E., et al., A variant associated with nicotine dependence, lung cancer and peripheral arterial disease. Nature, 2008. 452(7187): p. 638-642.

6. Gazdar, A., et al., Hereditary lung cancer syndrome targets never smokers with germline EGFR gene T79oM mutations. Journal of Thoracic Oncology, 2014. 9(4): p. 456-463.

7. Doll, R. and R. Peto, Mortality in relation to smoking: 20 years' observations on male British doctors. British Medical Journal, 1976. 2(6051): p. 1525-1536.

8. Doll, R., et al., Mortality in relation to smoking: 50 Years' observations on male British doctors. British Medical Journal, 2004. 328(7455): p. 1519-1528.

9. Hirayama, T., Nonsmoking wives of heavy smokers have a higher risk of lung cancer: A study from Japan. British Medical Journal (Clinical research ed.), 1981. 282(6259): p. 183-185.

10. Alavanja, M., et al., Tobacco smoke and involuntary smoking, in IARC Monographs on the Evaluation of Carcinogenic Risks to Humans. 2004. p. 11413 .

11. Krewski, D., et al., Residential radon and risk of lung cancer: A combined analysis of 7 North American case-control studies. Epidemiology, 2005. 16(2): p. $137-145$.

12. Boffetta, P., N. Jourenkova, and P. Gustavsson, Cancer risk from occupational and environmental exposure to polycyclic aromatic hydrocarbons. Cancer Causes and Control, 1997. 8(3): p. 444-472.

13. Mossman, B.T., et al., Asbestos: Scientific developments and implications for public policy. Science, 1990. 247(4940): p. 294-301.

14. Lacasse, Y., et al., Dose-response meta-analysis of silica and lung cancer. Cancer Causes and Control, 2009. 20(6): p. 925-933.

15. NationalCancerInstitute. SEER*Explorer: An interactive website for SEER cancer statistics [Internet]. Surveillance Research Program. Available from https://seer.cancer.gov/explorer/. [cited 2019 Nov 25].

16. Blandin Knight, S., et al., Progress and prospects of early detection in lung cancer. Open biology, 2017. 7(9): p. 170070.

17. MacDonald, V., Chemotherapy: managing side effects and safe handling. The Canadian veterinary journal $=$ La revue veterinaire canadienne, 2009. 50(6): $\mathrm{p}$. 665-668.

18. Lupu, I., et al., Cutaneous adverse reactions specific to epidermal growth factor receptor inhibitors. Journal of medicine and life, 2015. 8 Spec Issue(Spec Issue): p. 57-61.

19. Bajwa, R., et al., Adverse Effects of Immune Checkpoint Inhibitors (Programmed Death-1 Inhibitors and Cytotoxic T-Lymphocyte-Associated Protein-4 
Inhibitors): Results of a Retrospective Study. Journal of clinical medicine research, 2019. 11(4): p. 225-236.

20. Liu, H.-b., et al., Skin Rash could Predict the Response to EGFR Tyrosine Kinase Inhibitor and the Prognosis for Patients with Non-Small Cell Lung Cancer: A Systematic Review and Meta-Analysis. PLoS ONE, 2013. 8(1): p. e55128.

21. Cancer Therapy Evaluation Program, Common Terminology Criteria for Adverse Events, Version 3.o, DCTD, NCI, NIH, DHHS

March 31, 2003 (http://ctep.cancer.gov), . Publish Date: August 9, 2006.

22. Baggstrom, M.Q., et al., Third-Generation Chemotherapy Agents in the Treatment of Advanced Non-small Cell Lung Cancer: A Meta-Analysis. Journal of Thoracic Oncology, 2007. 2(9): p. 845-853.

23. Gronberg, B.H., et al., Phase III study by the Norwegian lung cancer study group: pemetrexed plus carboplatin compared with gemcitabine plus carboplatin as first-line chemotherapy in advanced non-small-cell lung cancer. J Clin Oncol, 2009. 27(19): p. 3217-24.

24. Fuertes, M.A., C. Alonso, and J.M. Pérez, Biochemical Modulation of Cisplatin Mechanisms of Action: Enhancement of Antitumor Activity and Circumvention of Drug Resistance. Chemical Reviews, 2003. 103(3): p. 645-662.

25. De Sousa Cavalcante, L. and G. Monteiro, Gemcitabine: Metabolism and molecular mechanisms of action, sensitivity and chemoresistance in pancreatic cancer. European Journal of Pharmacology, 2014. 741: p. 8-16.

26. Plunkett, W., et al., Gemcitabine: Metabolism, mechanisms of action, and selfpotentiation. Seminars in Oncology, 1995. 22(4 SUPPL. 11): p. 3-10.

27. Barton-Burke, M., Gemcitabine: A pharmacologic and clinical overview. Cancer Nursing, 1999. 22(2): p. 176-183.

28. Calvert, A.H., et al., Early clinical studies with cis-diammine-1,1-cyclobutane dicarboxylate platinum II. Cancer Chemotherapy and Pharmacology, 1982. 9(3): p. 140-147.

29. Sederholm, C., et al., Phase III trial of gemcitabine plus carboplatin versus single-agent gemcitabine in the treatment of locally advanced or metastatic non-small-cell lung cancer: the Swedish Lung Cancer Study Group. J Clin Oncol, 2005. 23(33): p. 8380-8.

30. Imamura, F., et al., Randomized phase II study of two schedules of carboplatin and gemcitabine for stage IIIB and IV advanced non-small cell lung cancer (JACCRO LC-O1 study). Chemotherapy, 2011. 57(4): p. 357-62.

31. Rudd, R.M., et al., Gemcitabine plus carboplatin versus mitomycin, ifosfamide, and cisplatin in patients with stage IIIB or IV non-small-cell lung cancer: A phase III randomized study of the London Lung Cancer Group. Journal of Clinical Oncology, 2005. 23(1): p. 142-153.

32. Crawford, J., et al., Reduction by Granulocyte Colony-Stimulating Factor of Fever and Neutropenia Induced by Chemotherapy in Patients with Small-Cell Lung Cancer. New England Journal of Medicine, 1991. 325(3): p. 164-170.

33. Groopman, J.E. and L.M. Itri, Chemotherapy-Induced Anemia in Adults: Incidence and Treatment. JNCI: Journal of the National Cancer Institute, 1999. 91(19): p. 1616-1634.

34. Miettinen, P.J., et al., Epithelial immaturity and multiorgan failure in mice lacking epidermal growth factor receptor. Nature, 1995. 376(6538): p. 337-341.

35. Sibilia, M. and E.F. Wagner, Strain-dependent epithelial defects in mice lacking the EGF receptor. Science, 1995. 269(5221): p. 234-238.

36. Threadgill, D., et al., Targeted disruption of mouse EGF receptor: effect of genetic background on mutant phenotype. Science, 1995. 269(5221): p. 230234.

37. Yarden, Y. and J. Schlessinger, Epidermal Growth Factor Induces Rapid, Reversible Aggregation of the Purified Epidermal Growth Factor Receptor. Biochemistry, 1987. 26(5): p. 1443-1451. 
38. Landau, M. and N. Ben-Tal, Dynamic equilibrium between multiple active and inactive conformations explains regulation and oncogenic mutations in ErbB receptors. Biochim Biophys Acta, 2008. 1785(1): p. 12-31.

39. Purba, E.R., E.-I. Saita, and I.N. Maruyama, Activation of the EGF Receptor by Ligand Binding and Oncogenic Mutations: The "Rotation Model". Cells, 2017. 6(2): p. 13 .

40. Hidalgo, M., et al., Phase I and pharmacologic study of OSI-774, an epidermal growth factor receptor tyrosine kinase inhibitor, in patients with advanced solid malignancies. Journal of Clinical Oncology, 2001. 19(13): p. 3267-3279.

41. Midha, A., S. Dearden, and R. McCormack, EGFR mutation incidence in nonsmall-cell lung cancer of adenocarcinoma histology: a systematic review and global map by ethnicity (mutMapII). American Journal of Cancer Research, 2015. 5(9): p. 2892-2911.

42. Moyer, J.D., et al., Induction of apoptosis and cell cycle arrest by CP-358,774, an inhibitor of epidermal growth factor receptor tyrosine kinase. Cancer Research, 1997. 57(21): p. 4838-4848.

43. Cappuzzo, F., et al., Erlotinib as maintenance treatment in advanced non-smallcell lung cancer: A multicentre, randomised, placebo-controlled phase 3 study. The Lancet Oncology, 2010. 11(6): p. 521-529.

44. Rosell, R., et al., Erlotinib versus standard chemotherapy as first-line treatment for European patients with advanced EGFR mutation-positive non-small-cell lung cancer (EURTAC): A multicentre, open-label, randomised phase 3 trial. The Lancet Oncology, 2012. 13(3): p. 239-246.

45. Shepherd, F.A., et al., Erlotinib in previously treated non-small-cell lung cancer. New England Journal of Medicine, 2005. 353(2): p. 123-132.

46. Nanney, L.B., et al., Immunolocalization of epidermal growth factor receptors in normal developing human skin. J Invest Dermatol, 1990. 94(6): p. 742-8.

47. Rugo, H.S., et al., The characterization, management, and future considerations for ErbB-family TKI-associated diarrhea. Breast Cancer Research and Treatment, 2019. 175(1): p. 5-15.

48. Wacker, B., et al., Correlation between Development of Rash and Efficacy in Patients Treated with the Epidermal Growth Factor Receptor Tyrosine Kinase Inhibitor Erlotinib in Two Large Phase III Studies. Clinical Cancer Research, 2007. 13(13): p. 3913-3921.

49. Fabbrocini, G., et al., Acneiform Rash Induced by EGFR Inhibitors: Review of the Literature and New Insights. Skin appendage disorders, 2015. 1(1): p. 31-37.

50. Hirsh, V., et al., Management of diarrhea induced by epidermal growth factor receptor tyrosine kinase inhibitors. Current oncology (Toronto, Ont.), 2014. 21(6): p. 329-336.

51. Lacouture, M.E., et al., Skin Toxicity Evaluation Protocol With Panitumumab (STEPP), a Phase II, Open-Label, Randomized Trial Evaluating the Impact of a Pre-Emptive Skin Treatment Regimen on Skin Toxicities and Quality of Life in Patients With Metastatic Colorectal Cancer. Journal of Clinical Oncology, 2010. 28(8): p. 1351-1357.

52. Uribe, J.M., et al., Epidermal growth factor inhibits $\mathrm{Ca}(2+)$-dependent $\mathrm{Cl}$ transport in T84 human colonic epithelial cells. American Journal of PhysiologyCell Physiology, 1996. 271(3): p. C914-C922.

53. Beech, J., et al., Management and grading of EGFR inhibitor-induced cutaneous toxicity. Future Oncology, 2018. 14(24): p. 2531-2541.

54. $\quad$ Roden, D.M., et al., Pharmacogenomics. Lancet, 2019. 394(10197): p. 521-532.

55. Huang, R.S. and M.J. Ratain, Pharmacogenetics and pharmacogenomics of anticancer agents. CA: a cancer journal for clinicians, 2009. 59(1): p. 42-55.

56. Pirmohamed, M., Personalized pharmacogenomics: predicting efficacy and adverse drug reactions. Annu Rev Genomics Hum Genet, 2014. 15: p. 349-70. 
57. U.S. Department of Health and Human Services, F.a.D.A., Center for Drug Evaluation and Research (CDER), Center for Biologics Evaluation and Research (CBER) E15 Pharmacogenomics Definitions and Sample Coding. 2008.

58. Rudin, C.M., et al., Pharmacogenomic and pharmacokinetic determinants of erlotinib toxicity. Journal of Clinical Oncology, 2008. 26(7): p. 1119-1127.

59. Tiseo, M., et al., Correlation between erlotinib pharmacokinetics, cutaneous toxicity and clinical outcomes in patients with advanced non-small cell lung cancer (NSCLC). Lung Cancer, 2014. 83(2): p. 265-71.

6o. Fukudo, M., et al., Population Pharmacokinetics/Pharmacodynamics of Erlotinib and Pharmacogenomic Analysis of Plasma and Cerebrospinal Fluid Drug Concentrations in Japanese Patients with Non-Small Cell Lung Cancer. Clinical Pharmacokinetics, 2013. 52(7): p. 593-609.

61. Steffens, M., et al., Dosing to rash?--The role of erlotinib metabolic ratio from patient serum in the search of predictive biomarkers for EGFR inhibitormediated skin rash. Eur J Cancer, 2016. 55: p. 131-9.

62. Nishimura, M., et al., Distribution of erlotinib in rash and normal skin in cancer patients receiving erlotinib visualized by matrix assisted laser desorption/ionization mass spectrometry imaging. Oncotarget, 2018. 9(26): p. 18540-18547.

63. Perez-Soler, R., et al., Determinants of tumor response and survival with erlotinib in patients with non--small-cell lung cancer. J Clin Oncol, 2004. 22(16): p. 3238-47.

64. Petrelli, F., et al., Relationship between skin rash and outcome in non-small-cell lung cancer patients treated with anti-EGFR tyrosine kinase inhibitors: A literature-based meta-analysis of 24 trials. Lung Cancer, 2012. 78(1): p. 8-15.

65. Parmar, S., et al., Pharmacogenetic predictors for EGFR-inhibitor-associated skin toxicity. Pharmacogenomics J, 2013. 13(2): p. 181-8.

66. Katsuya, Y., et al., Comparison of the pharmacokinetics of erlotinib administered in complete fasting and $2 \mathrm{~h}$ after a meal in patients with lung cancer. Cancer Chemotherapy and Pharmacology, 2015. 76(1): p. 125-132.

67. Ling, J., et al., Effect of food on the pharmacokinetics of erlotinib, an orally active epidermal growth factor receptor tyrosine-kinase inhibitor, in healthy individuals. Anticancer Drugs, 2008. 19(2): p. 209-16.

68. Li, J., et al., Association of variant ABCG2 and the pharmacokinetics of epidermal growth factor receptor tyrosine kinase inhibitors in cancer patients. Cancer Biol Ther, 2007. 6(3): p. 432-8.

69. Noguchi, K., et al., Substrate-dependent bidirectional modulation of $P$ glycoprotein-mediated drug resistance by erlotinib. Cancer Sci, 2009. 100(9): p. 1701-7.

70. Hodges, L.M., et al., Very important pharmacogene summary: ABCB1 (MDR1, P-glycoprotein). Pharmacogenetics and genomics, 2011. 21(3): p. 152-161.

71. Horsey, Aaron J., et al., The multidrug transporter ABCG2: still more questions than answers. Biochemical Society Transactions, 2016. 44(3): p. 824-830.

72. Marchetti, S., et al., Effect of the ATP-binding cassette drug transporters ABCB1, ABCG2, and ABCC2 on erlotinib hydrochloride (Tarceva) disposition in in vitro and in vivo pharmacokinetic studies employing Bcrp1-/-/Mdr1a/1b-/- (tripleknockout) and wild-type mice. Molecular Cancer Therapeutics, 2008. 7(8): p. 2280-2287.

73. Li, J., et al., Differential metabolism of gefitinib and erlotinib by human cytochrome P45o enzymes. Clinical Cancer Research, 2007. 13(12): p. 3731-3737.

74. Agency, E.M. Tarceva: EPAR - Product Information. 2019; Available from: https://www.ema.europa.eu/en/medicines/human/EPAR/tarceva.

75. Hamilton, M., et al., Effects of smoking on the pharmacokinetics of erlotinib. Clinical Cancer Research, 2006. 12(7 I): p. 2166-2171.

76. Klein, K., et al., PPARA: A novel genetic determinant of $C Y P_{3} A_{4}$ in vitro and in vivo. Clinical Pharmacology and Therapeutics, 2012. 91(6): p. 1044-1052. 
77. Diczfalusy, U., et al., 4beta-hydroxycholesterol as an endogenous marker for $\mathrm{CYP}_{3} \mathrm{~A}_{4} / 5$ activity. Stability and half-life of elimination after induction with rifampicin. Br J Clin Pharmacol, 2009. 67(1): p. 38-43.

78. Hunt, C.M., W.R. Westerkam, and G.M. Stave, Effect of age and gender on the activity of human hepatic CYP3A. Biochem Pharmacol, 1992. 44(2): p. 275-83.

79. Smith, N.F., et al., Modulation of erlotinib pharmacokinetics in mice by a novel cytochrome P45O $3 A 4$ inhibitor, BAS 10O. British journal of cancer, 2008. 98(10): p. 1630-1632.

80. Endo-Tsukude, C., et al., Population Pharmacokinetics and Adverse Events of Erlotinib in Japanese Patients with Non-small-cell Lung Cancer: Impact of Genetic Polymorphisms in Metabolizing Enzymes and Transporters. Biol Pharm Bull, 2018. 41(1): p. 47-56.

81. Wang, C., et al., Genetic Association of Drug Response to Erlotinib in Chinese Advanced Non-small Cell Lung Cancer Patients. Frontiers in pharmacology, 2018. 9: p. 360-360.

82. Ruan, Y., et al., Genetic Association of Curative and Adverse Reactions to Tyrosine Kinase Inhibitors in Chinese advanced Non-Small Cell Lung Cancer patients. Scientific Reports, 2016. 6: p. 23368.

83. Arbitrio, M., et al., Identification of polymorphic variants associated with erlotinib-related skin toxicity in advanced non-small cell lung cancer patients by DMET microarray analysis. Cancer Chemotherapy and Pharmacology, 2016. 77(1): p. 205-209.

84. Chen, X., et al., Impact of ABCG2 polymorphisms on the clinical outcome of TKIs therapy in Chinese advanced non-small-cell lung cancer patients. Cancer Cell Int, 2015. 15: p. 43.

85. Hasheminasab, S.M., et al., High-throughput screening identified inherited genetic variations in the EGFR pathway contributing to skin toxicity of EGFR inhibitors. Pharmacogenomics, 2015. 16(14): p. 1605-19.

86. Larsen, A.W., et al., EGFR CA repeat polymorphism predict clinical outcome in EGFR mutation positive NSCLC patients treated with erlotinib. Lung Cancer, 2014. 85(3): p. 435-441.

87. Hamada, A., et al., Association of $A B C B 1$ polymorphisms with erlotinib pharmacokinetics and toxicity in Japanese patients with non-small-cell lung cancer. Pharmacogenomics, 2012. 13(5): p. 615-24.

88. Liu, G., et al., Pharmacogenetic analysis of BR.21, a placebo-controlled randomized phase III clinical trial of erlotinib in advanced non-small cell lung cancer. J Thorac Oncol, 2012. 7(2): p. 316-22.

89. Amador, M.L., et al., An epidermal growth factor receptor intron 1 polymorphism mediates response to epidermal growth factor receptor inhibitors. Cancer Research, 2004. 64(24): p. 9139-9143.

90. Imai, Y., et al., C421A polymorphism in the human breast cancer resistance protein gene is associated with low expression of Q141K protein and low-level drug resistance. Mol Cancer Ther, 2002. 1(8): p. 611-6.

91. Kondo, C., et al., Functional Analysis of SNPS Variants of BCRP/ABCG2. Pharmaceutical Research, 2004. 21(10): p. 1895-1903.

92. Chang, I.S., et al., Genetic Modifiers of Progression-Free Survival in NeverSmoking Lung Adenocarcinoma Patients Treated with First-Line Tyrosine Kinase Inhibitors. Am J Respir Crit Care Med, 2017. 195(5): p. 663-673.

93. Tibaldi, C., et al., Correlation of cytidine deaminase polymorphisms and activity with clinical outcome in gemcitabine-/platinum-treated advanced non-smallcell lung cancer patients. Ann Oncol, 2012. 23(3): p. 670-7.

94. Joerger, M., et al., Gene polymorphisms, pharmacokinetics, and hematological toxicity in advanced non-small-cell lung cancer patients receiving cisplatin/gemcitabine. Cancer Chemotherapy and Pharmacology, 2012. 69(1): p. 25-33. 
95. Giovannetti, E., et al., Correlation Between Cytidine Deaminase Genotype and Gemcitabine Deamination in Blood Samples. Nucleosides, Nucleotides and Nucleic Acids, 2008. 27(6-7): p. 720-725.

96. Ding, X., et al., Cytidine deaminase polymorphism predicts toxicity of gemcitabine-based chemotherapy. Gene, 2015. 559(1): p. 31-37.

97. $\mathrm{Xu}, \mathrm{J} .$, et al., High incidence of severe neutropenia after gemcitabine-based chemotherapy in Chinese cancer patients with CDA $79 A>C$ mutation. Clinica Chimica Acta, 2012. 413(15-16): p. 1284-1287.

98. Maring, J.G., et al., Pharmacokinetics of gemcitabine in non-small-cell lung cancer patients: Impact of the $79 A>C$ cytidine deaminase polymorphism. European Journal of Clinical Pharmacology, 2010. 66(6): p. 611-617.

99. Li, H., X. Wang, and X. Wang, The impact of CDA A79C gene polymorphisms on the response and hematologic toxicity in gemcitabine-treated patients: A metaanalysis. International Journal of Biological Markers, 2014. 29(3): p. e224-e232.

100. Tibaldi, C., et al., Correlation of CDA, ERCC1, and XPD polymorphisms with response and survival in gemcitabine/cisplatin-treated advanced non-small cell lung cancer patients. Clinical Cancer Research, 2008. 14(6): p. 1797-1803.

101. Zheng, Y., et al., The association of genetic variations in DNA repair pathways with severe toxicities in NSCLC patients undergoing platinum-based chemotherapy. Int J Cancer, 2017. 141(11): p. 2336-2347.

102. Ludovini, V., et al., Association of cytidine deaminase and xeroderma pigmentosum group D polymorphisms with response, toxicity, and survival in cisplatin/gemcitabine- treated advanced non-small cell lung cancer patients. Journal of Thoracic Oncology, 2011. 6(12): p. 2018-2026.

103. Perez-Ramirez, C., et al., Pharmacogenetic predictors of toxicity to platinum based chemotherapy in non-small cell lung cancer patients. Pharmacol Res, 2016. 111: p. 877-884.

104. Chu, T.-q., et al., RAD18 polymorphisms are associated with platinum-based chemotherapy toxicity in Chinese patients with non-small cell lung cancer. Acta Pharmacologica Sinica, 2016. 37: p. 1490.

105. Wu, W., et al., Association of \&lt;em\&gt;XPD\&lt;/em\&gt; Polymorphisms with Severe Toxicity in Non-Small Cell Lung Cancer Patients in a Chinese Population. Clinical Cancer Research, 2009. 15(11): p. 3889.

106. Wang, Z., et al., XRCC1 polymorphisms and severe toxicity in lung cancer patients treated with cisplatin-based chemotherapy in Chinese population. Lung Cancer, 2008. 62(1): p. 99-104.

107. Zhang, L., et al., Association between Single Nucleotide Polymorphisms (SNPs) and Toxicity of Advanced Non-Small-Cell Lung Cancer Patients Treated with Chemotherapy. PLoS ONE, 2012. 7(10).

108. Chu, T.Q., et al., RAD18 polymorphisms are associated with platinum-based chemotherapy toxicity in Chinese patients with non-small cell lung cancer. Acta Pharmacologica Sinica, 2016. 37(11): p. 1490-1498.

109. Cao, S., et al., Genome-wide association study of myelosuppression in nonsmall-cell lung cancer patients with platinum-based chemotherapy. Pharmacogenomics J, 2015.

110. Kiyotani, K., et al., A genome-wide association study identifies four genetic markers for hematological toxicities in cancer patients receiving gemcitabine therapy. Pharmacogenet Genomics, 2012. 22(4): p. 229-35.

111. Low, S.K., et al., Genome-wide association study of chemotherapeutic agentinduced severe neutropenia/leucopenia for patients in Biobank Japan. Cancer Sci, 2013. 104(8): p. 1074-82.

112. Principles and Techniques of Biochemistry and Molecular Biology. 7 ed. 2010, Cambridge: Cambridge University Press.

113. Joseph C. Arsenault, P.D.M., Beginners Guide to Liquid Chromatography 2007.

114. Balogh, M.P., The Mass Spectrometry Primer. 2009. 
115. Hohmann, N., W.E. Haefeli, and G. Mikus, CYP3A activity: towards dose adaptation to the individual. Expert Opinion on Drug Metabolism \& Toxicology, 2016. 12(5): p. 479-497.

116. Mirghani, R.A., et al., Quinine 3-hydroxylation as a biomarker reaction for the activity of $\mathrm{CYP}_{3} \mathrm{~A}_{4}$ in man. European Journal of Clinical Pharmacology, 2003. 59(1): p. 23-28.

117. Nylén, H., et al., Plasma Levels of 25-Hydroxyvitamin D3 and In Vivo Markers of Cytochrome P450 3 A Activity in Swedes and Koreans: Effects of a Genetic Polymorphism and Oral Contraceptives. Basic \& Clinical Pharmacology \& Toxicology, 2014. 115(4): p. 366-371.

118. Fuhr, U., A. Jetter, and J. Kirchheiner, Appropriate Phenotyping Procedures for Drug Metabolizing Enzymes and Transporters in Humans and Their Simultaneous Use in the "Cocktail" Approach. Clinical Pharmacology \& Therapeutics, 2007. 81(2): p. 270-283.

119. Bodin, K., et al., Antiepileptic Drugs Increase Plasma Levels of $4 \beta$ Hydroxycholesterolin Humans: EVIDENCE FOR INVOLVEMENT OF CYTOCHROME P45O 3A4. Journal of Biological Chemistry, 2001. 276(42): p. 38685-38689.

120. Ged, C., et al., The increase in urinary excretion of 6 beta-hydroxycortisol as a marker of human hepatic cytochrome P450IIIA induction. Br J Clin Pharmacol, 1989. 28(4): p. 373-87.

121. Mirghani, R.A., et al., Simultaneous determination of quinine and four metabolites in plasma and urine by high-performance liquid chromatography. Journal of Chromatography B: Biomedical Sciences and Applications, 2001. 754(1): p. 57-64.

122. Skoglund, K., et al., In Vivo Cytochrome P45O $3 A$ Isoenzyme Activity and Pharmacokinetics of Imatinib in Relation to Therapeutic Outcome in Patients With Chronic Myeloid Leukemia. Ther Drug Monit, 2016. 38(2): p. 230-8.

123. Asha, S. and M. Vidyavathi, Role of Human Liver Microsomes in In Vitro Metabolism of Drugs $-A$ Review. Applied Biochemistry and Biotechnology, 2010. 160(6): p. 1699-1722.

124. Ling, J., et al., Metabolism and excretion of erlotinib, a small molecule inhibitor of epidermal growth factor receptor tyrosine kinase, in healthy male volunteers. Drug Metabolism and Disposition, 2006. 34(3): p. 420-426.

125. Lozzio, C.B. and B.B. Lozzio, Human chronic myelogenous leukemia cell-line with positive Philadelphia chromosome. Blood, 1975. 45(3): p. 321-34.

126. Skoglund, K., et al., Single-nucleotide polymorphisms of ABCG2 increase the efficacy of tyrosine kinase inhibitors in the K562 chronic myeloid leukemia cell line. Pharmacogenetics and Genomics, 2014. 24(1): p. 52-61.

127. DeKoter, R.P., et al., Regulation of the interleukin-7 receptor alpha promoter by the Ets transcription factors PU.1 and GA-binding protein in developing B cells. The Journal of biological chemistry, 2007. 282(19): p. 14194-14204.

128. Steemers, F.J. and K.L. Gunderson, Whole genome genotyping technologies on the BeadArray ${ }^{\mathrm{TM}}$ platform. Biotechnology Journal, 2007. 2(1): p. 41-49.

129. Dean, F.B., et al., Comprehensive human genome amplification using multiple displacement amplification. Proceedings of the National Academy of Sciences of the United States of America, 2002. 99(8): p. 5261-5266.

130. Gunderson, K.L., et al., Decoding randomly ordered DNA arrays. Genome Res, 2004. 14(5): p. 870-7.

131. Steemers, F.J., et al., Whole-genome genotyping with the single-base extension assay. Nature Methods, 2006. 3(1): p. 31-33.

132. Shinde, D., et al., Taq DNA polymerase slippage mutation rates measured by $P C R$ and quasi-likelihood analysis: $(C A / G T) n$ and $(A / T) n$ microsatellites. Nucleic Acids Research, 2003. 31(3): p. 974-980. 
133. Marine, R., et al., Evaluation of a Transposase Protocol for Rapid Generation of Shotgun High-Throughput Sequencing Libraries from Nanogram Quantities of DNA. Applied and Environmental Microbiology, 2011. 77(22): p. 8071-8079.

134. Fedurco, M., et al., BTA, a novel reagent for DNA attachment on glass and efficient generation of solid-phase amplified DNA colonies. Nucleic Acids Research, 2006. 34(3).

135. Bentley, D.R., et al., Accurate whole human genome sequencing using reversible terminator chemistry. Nature, 2008. 456(7218): p. 53-59.

136. Metzker, M.L., Sequencing technologies - the next generation. Nat Rev Genet, 2010. 11(1): p. 31-46.

137. Goodwin, S., J.D. McPherson, and W.R. McCombie, Coming of age: ten years of next-generation sequencing technologies. Nat Rev Genet, 2016. 17(6): p. 333-51.

138. Depristo, M.A., et al., A framework for variation discovery and genotyping using next-generation DNA sequencing data. Nature Genetics, 2011. 43(5): p. 491-501.

139. U.S Department of Health and Human Services, Food and Drug Administration, Center for Drug Evaluation and Research (CDER), Center for Veterinary Medicine (CVM), Guidance for Industry Bioanalytical Method Validation. 2001.

140. European Medicines Agency (EMA), Committe for Medicinal Proucts or Human Use (CHMP), Guideline on Bioanalytichal Method Validation. 2011.

141. Ishida, T., T. Naito, and J. Kawakami, Simultaneous determination of erlotinib and its isomeric major metabolites in human plasma using isocratic liquid chromatography-tandem mass spectrometry and its clinical application. Biomedical Chromatography, 2015. 29(5): p. 643-646.

142. Lepper, E.R., et al., Liquid-chromatographic determination of erlotinib (OSI774), an epidermal growth factor receptor tyrosine kinase inhibitor. Journal of Chromatography B: Analytical Technologies in the Biomedical and Life Sciences, 2003. 796(1): p. 181-188.

143. Mandal, B., et al., Development and validation of a spectrofluorimetric method for the determination of erlotinib in spiked human plasma. Journal of Fluorescence, 2012. 22(6): p. 1425-1429.

144. Pan, J., X. Jiang, and Y.L. Chen, Automatic supported liquid extraction (SLE) coupled with HILIC-MS/MS: An application to method development and validation of erlotinib in human plasma. Pharmaceutics, 2010. 2(2): p. 105-118.

145. Lankheet, N.A.G., et al., Quantitative determination of erlotinib and $O$ desmethyl erlotinib in human EDTA plasma and lung tumor tissue. Bioanalysis, 2012. 4(21): p. 2563-2577.

146. Masters, A.R., C.J. Sweeney, and D.R. Jones, The quantification of erlotinib (OSI774) and OSI-42O in human plasma by liquid chromatography-tandem mass spectrometry. Journal of Chromatography B: Analytical Technologies in the Biomedical and Life Sciences, 2007. 848(2): p. 379-383.

147. Signor, L., et al., Analysis of erlotinih and its metabolites in rat tissue sections by MALDI quadrupole time-of-flight mass spectrometry. Journal of Mass Spectrometry, 2007. 42(7): p. 900-909.

148. Zhang, W., et al., Simultaneous determination of OSI-774 and its major metabolite OSI-42O in human plasma by using HPLCwith UV detection. Journal of Chromatography B, 2005. 814(1): p. 143-147.

149. Zhao, M., et al., Specific method for determination of OSI-774 and its metabolite OSI-42O in human plasma by using liquid chromatography-tandem mass spectrometry. Journal of Chromatography B: Analytical Technologies in the Biomedical and Life Sciences, 2003. 793(2): p. 413-420.

150. Bouchet, S., et al., Simultaneous determination of nine tyrosine kinase inhibitors by 96-well solid-phase extraction and ultra performance LC/MS-MS. Clinica Chimica Acta, 2011. 412(11-12): p. 1060-1067. 
151. Chahbouni, A., et al., Simultaneous quantification of erlotinib, gefitinib, and imatinib in human plasma by liquid chromatography tandem mass spectrometry. Therapeutic Drug Monitoring, 2009. 31(6): p. 683-687.

152. Faivre, L., et al., A simple HPLC-UV method for the simultaneous quantification of gefitinib and erlotinib in human plasma. Journal of Chromatography B: Analytical Technologies in the Biomedical and Life Sciences, 2011. 879(23): p. 2345-2350.

153. Götze, L., et al., Development and clinical application of a LC-MS/MS method for simultaneous determination of various tyrosine kinase inhibitors in human plasma. Clinica Chimica Acta, 2012. 413(1-2): p. 143-149.

154. Honeywell, R., et al., Simple and selective method for the determination of various tyrosine kinase inhibitors used in the clinical setting by liquid chromatography tandem mass spectrometry. Journal of Chromatography B: Analytical Technologies in the Biomedical and Life Sciences, 2010. 878(15-16): p. 1059-1068.

155. Thul, P.J., et al., A subcellular map of the human proteome. Science, 2017. 356(6340).

156. Imai, Y., et al., C421A polymorphism in the human breast cancer resistance protein gene is associated with low expression of Q141K protein and low-level drug resistance. Molecular Cancer Therapeutics, 2002. 1(8): p. 611-616.

157. Liao, D., et al., Correlation of plasma erlotinib trough concentration with skin rash in Chinese NSCLC patients harboring exon 19 deletion mutation. Cancer Chemother Pharmacol, 2018. 82(3): p. 551-559.

158. Lu, J.F., et al., Clinical pharmacokinetics of erlotinib in patients with solid tumors and exposure-safety relationship in patients with non-small cell lung cancer. Clin Pharmacol Ther, 2006. 80(2): p. 136-45.

159. Wind, S., et al., Clinical Pharmacokinetics and Pharmacodynamics of Afatinib. Clinical pharmacokinetics, 2017. 56(3): p. 235-250.

160. Khozin, S., et al., Osimertinib for the Treatment of Metastatic EGFR T79oM Mutation-Positive Non-Small Cell Lung Cancer. Clin Cancer Res, 2017. 23(9): p. 2131-2135.

161. Lamba, J.K., et al., Genetic contribution to variable human CYP3A-mediated metabolism. Advanced Drug Delivery Reviews, 2002. 54(10): p. 1271-1294.

162. Calvert, H., et al., Effect of erlotinib on CYP3A activity, evaluated in vitro and by dual probes in patients with cancer. Anticancer Drugs, 2014. 25(7): p. 832-40.

163. Diczfalusy, U., et al., $4 \beta-H y$ droxycholesterol is a new endogenous $C_{3} P_{3} A$ marker: Relationship to CYP3A5 genotype, quinine 3-hydroxylation and sex in Koreans, Swedes and Tanzanians. Pharmacogenetics and Genomics, 2008. 18(3): p. 201-208.

164. Tamura, M., et al., Genetic polymorphisms of the adenosine triphosphatebinding cassette transporters ( $A B C G 2, A B C B 1$ ) and gefitinib toxicity. Nagoya $J$ Med Sci, 2012. 74(1-2): p. 133-40. 


\section{Papers}

The papers associated with this thesis have been removed for copyright reasons. For more details about these see:

http://urn.kb.se/resolve?urn=urn:nbn:se:liu:diva-163123 



\section{FACULTY OF MEDICINE AND HEALTH SCIENCES}

Linköping University Medical Dissertation No. 1708, 2020

Department of Biomedical and Clinical Sciences

Linköping University

SE-581 83 Linköping, Sweden

www.liu.se 